\title{
THE RESULT OF GENERALIZATION: BEARING THE CONSEQUENCES OF IMPRECISELY DESIGNATING TERRORIST ORGANIZATIONS
}

\author{
A Monograph \\ by \\ MAJ Christopher M. Hodl \\ United States Army

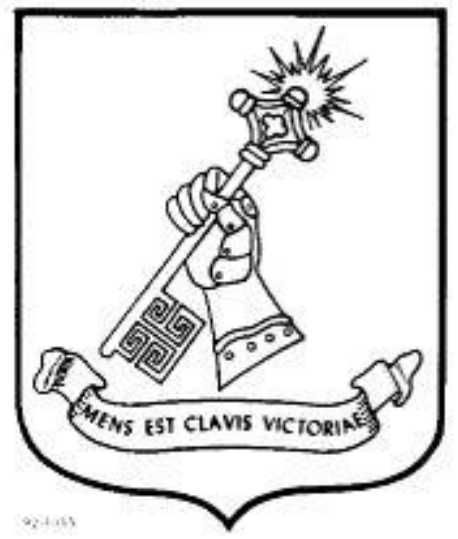 \\ School of Advanced Military Studies \\ United States Army Command and General Staff College \\ Fort Leavenworth, Kansas \\ 2014-01
}

Approved for public release; distribution is unlimited. 


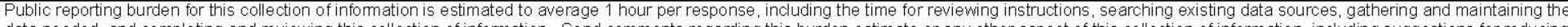

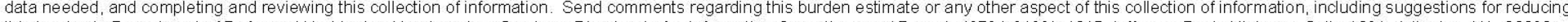

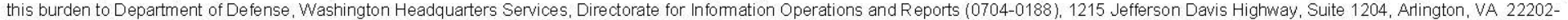

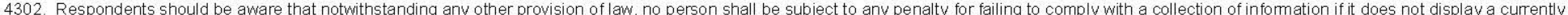
valid OMB control number. PLEASE DO NOT RETURN YOUR FORM TO THE ABOVE ADDRESS.

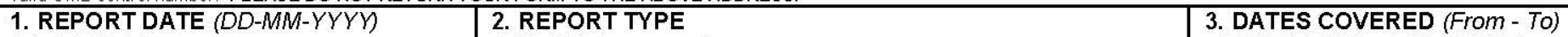

\begin{tabular}{l|l} 
23-04-2014 & SAMS Monograph
\end{tabular}

4. TITLE AND SUBTITLE

The Result of Generalization: Bearing the Consequences of Imprecisely Designating Terrorist Organizations JNE 2013 - MAY 2014 5a. CONTRACT NUMBER

5b. GRANT NUMBER

5c. PROGRAM ELEMENT NUMBER

6. AUTHOR(S)

5d. PROJECT NUMBER

Major Christopher M. Hodl, U.S. Army

5e. TASK NUMBER

5f. WORK UNIT NUMBER

7. PERFORMING ORGANIZATION NAME(S) AND ADDRESS(ES)

8. PERFORMING ORGANIZATION REPORT

U.S. Army School of Advanced Military Studies

ATTN: ATZL-SWD-GD

1 Reynolds Ave.

Fort Leavenworth, KS 66027-2301

9. SPONSORING / MONITORING AGENCY NAME(S) AND ADDRESS(ES)

10. SPONSOR/MONITOR'S ACRONYM(S)

11. SPONSOR/MONITOR'S REPORT NUMBER(S)

\section{DISTRIBUTION / AVAILABILITY STATEMENT}

Approved for Public Release; Distribution is Unlimited

13. SUPPLEMENTARY NOTES

\section{ABSTRACT}

What is the effect of the United States ineffectively designating terrorist organizations on military and diplomatic operations? Establishing a practicable definition of terrorism is a pursuit that invariably leads to vagueness to compensate for context and allow for discretion in application. The resulting effect on criteria for designating terrorist organizations creates a framework that may encompass almost any act of violence if applied incorrectly. As such, this monograph attempts to identify the issues with the definition and framework that prevent effective application of terrorist organization designations and provide options for improvement. This is accomplished through identification of the statutory terrorism definition's characteristics, an introduction of the terrorism designation framework and case studies of two organizations listed and subsequently delisted as terrorist organizations. Content of the research also includes academic discussion of the characteristics of a definition of terrorism and the current statutory framework to identify strengths and weaknesses. Analysis of research indicated that the statutory definition and designation framework allow excessive discretion in designating terrorist organizations, leading to negative effects on diplomatic and military operations. As currently employed, there is little restriction in the designation of foreign violent groups oppose their government as terrorist organizations. Consequently, there is wide discretion in designating groups as terrorist without understanding their purpose, complicating operations and delegitimizing the designation process.

\section{SUBJECT TERMS}

Statutory Definition of Terrorism; Foreign Terrorist Organizations; Specially Designated Global Terrorist.

\begin{tabular}{|c|c|c|c|c|c|}
\hline \multicolumn{3}{|c|}{ 16. SECURITY CLASSIFICATION OF: } & \multirow{2}{*}{$\begin{array}{l}\text { 17. LIMITATION } \\
\text { OF ABSTRACT }\end{array}$} & \multirow{2}{*}{$\begin{array}{l}\text { 18. NUMBER } \\
\text { OF PAGES }\end{array}$} & 19a. NAME OF RESPONSIBLE PERSON \\
\hline a. REPORT & b. ABSTRACT & c. THIS PAGE & & & 19b. TELEPHONE NUMBER (include area code) \\
\hline U & $\mathrm{U}$ & $\mathrm{U}$ & UU & 72 & \\
\hline
\end{tabular}




\section{MONOGRAPH APPROVAL PAGE}

Name of Candidate: MAJ Christopher M. Hodl

Monograph Title: The Result of Generalization: Bearing The Consequences of Imprecisely Designating Terrorist Organizations

Approved by:

Alice Butler-Smith, Ph.D.

, Monograph Director

, Seminar Leader

Jerry A. Turner, COL

, Director, School of Advanced Military Studies

Henry A. Arnold III, COL

Accepted this 22nd day of May 2013 by:

, Director, Graduate Degree Programs

Robert F. Baumann, Ph.D.

The opinions and conclusions expressed herein are those of the student author and do not necessarily represent the views of the U.S. Army Command and General Staff College or any other governmental agency. (References to this study should include the foregoing statement.) 


\begin{abstract}
THE RESULT OF GENERALIZATION: BEARING THE CONSEQUENCES OF IMPRECISELY DESIGNATING TERRORIST ORGANIZATIONS, by MAJ Christopher M. Hodl, 72 pages.
\end{abstract}

What is the effect of the United States ineffectively designating terrorist organizations on military and diplomatic operations? Establishing a practicable definition of terrorism is a pursuit that invariably leads to vagueness to compensate for context and allow for discretion in application. The resulting effect on criteria for designating terrorist organizations creates a framework that may encompass almost any act of violence if applied incorrectly. As such, this monograph attempts to identify the issues with the definition and framework that prevent effective application of terrorist organization designations and provide options for improvement. This is accomplished through identification of the statutory terrorism definition's characteristics, an introduction of the terrorism designation framework and case studies of two organizations listed and subsequently delisted as terrorist organizations.

Content of the research also includes academic discussion of the characteristics of a definition of terrorism and the current statutory framework to identify strengths and weaknesses. Findings from this research and analysis of information indicated that the statutory definition and designation framework allow excessive discretion in designating terrorist organizations, leading to negative effects on diplomatic and military operations. As currently employed, there is little restriction in the designation of foreign violent groups oppose their government as terrorist organizations. Consequently, there is wide discretion in designating groups as terrorist without understanding their purpose, complicating operations and delegitimizing the designation process. 


\section{ACKNOWLEDGMENTS}

This research could not have been accomplished without the steadfast support of many people who provided their insights, suggestions, motivation and, when needed, a shove in the right direction. The many who provided insight, reviews, thoughts and words of encouragement cannot be adequately thanked in the space provided, but there are special few who must be recognized. The foundation of this support is my wife and children who were enduring cheerleaders and supporters as they encouraged my endless obsession with this topic, to the detriment their time with me. Dr. Alice Butler-Smith provided a tireless eye and ear for my wandering ideas and writing and, when required, affixed my blinders and pointed me in the right direction even when I did not understand the path. The sound counsel and mentorship of COL Jerry Turner guided me through the pitfalls of the topic and its associated research. The patience and feedback from my syndicate-brothers was endless and appreciated, especially from MAJ Jose Vazquez and Mr. Anthony Volino, who endured more drafts of this paper than is considered humane. The steady encouragement of MAJs John "JD” Davis, Paul Godson and Rich Milloy provided a vision of the light at the end of the monograph tunnel. The collective virtues and accolades of this research belong to those who supported me so well, while I am solely responsible for its shortcomings and inadequacies. For without the guidance and patience of the above and many others, this paper would not have reached its completed state. 


\section{TABLE OF CONTENTS}

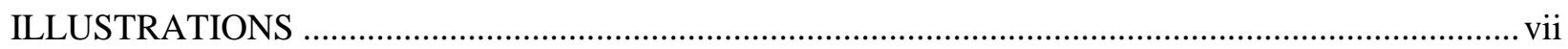

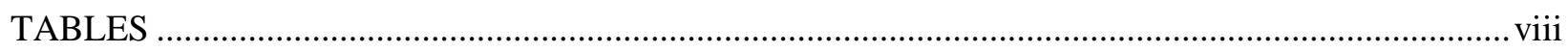

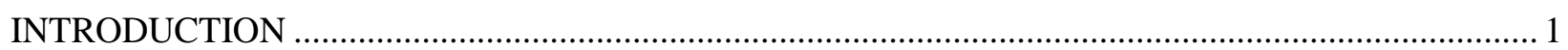

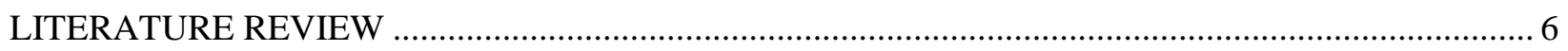

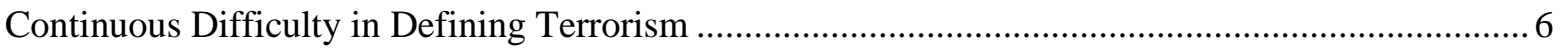

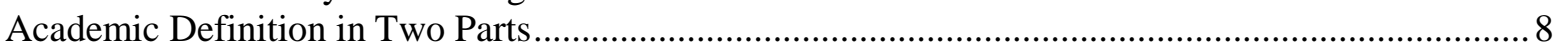

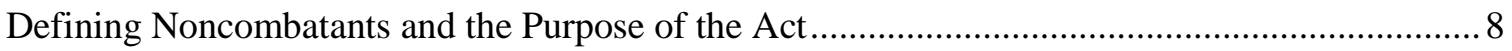

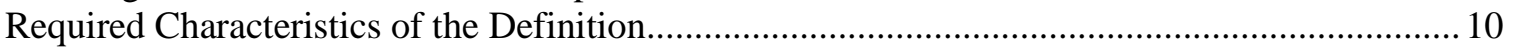

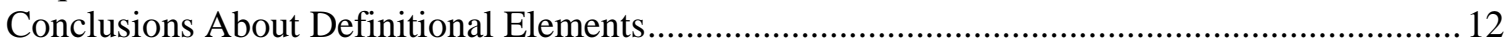

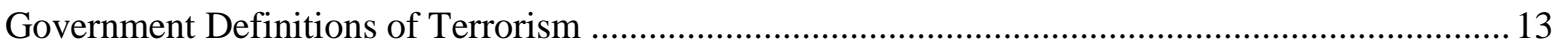

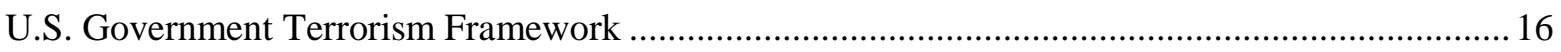

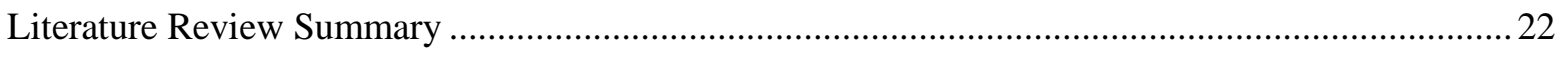

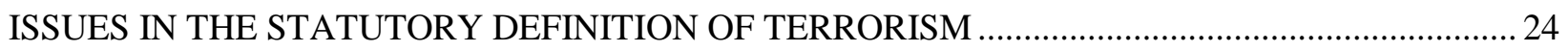

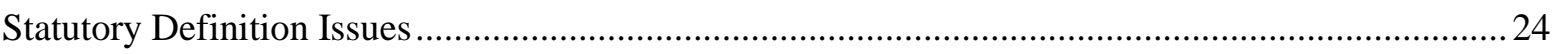

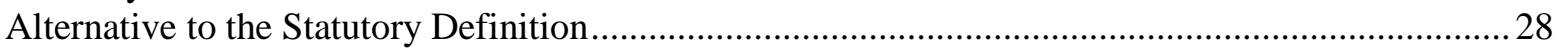

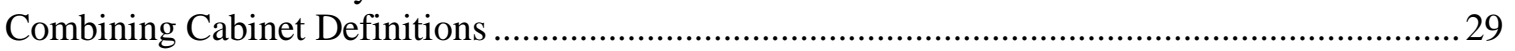

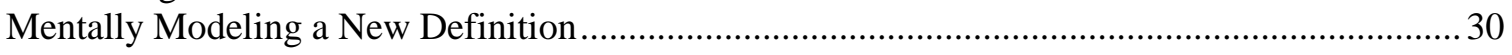

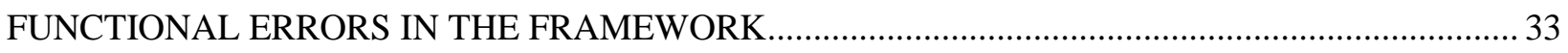

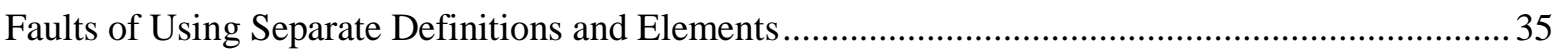

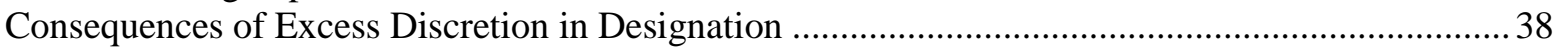

Narrowing a Discretionary Designation Process .................................................................... 40

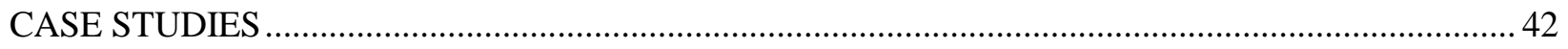

The Mujahedin-e Khalq and the United States ............................................................................. 42

The Communist Party of Nepal (Maoist) and the United States ................................................. 49

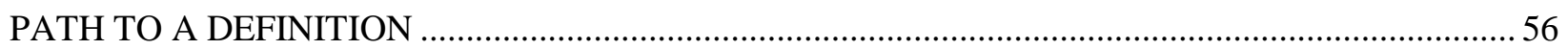

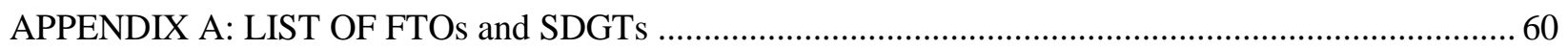

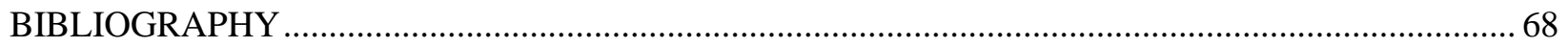




\section{ACRONYMS}

CPN(M) Communist Party of Nepal (Maoist)

DoD Department of Defense

DoS Department of State

E.O. Executive Order

FRAA Foreign Relations Authorization Act

FTO Foreign Terrorist Organization

MeK Mujahedin-e Khalq

OFAC Office of Foreign Asset Control

PMOI People's Mujahedin Organization of Iran

SDGT Specially Designated Global Terrorist

SDN Specially Designated National

SDT Specially Designated Terrorists

TEL Terrorist Exclusion List

U.S.C. United States Code 


\section{ILLUSTRATIONS}

Page

Figure 1. Model of Guerilla Tactics vs. Terrorism .... 30 
TABLES

Page

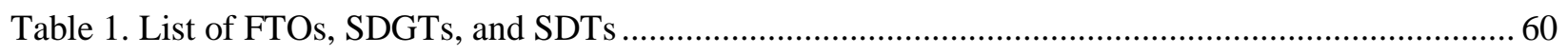




\section{INTRODUCTION}

Any definition of political terrorism venturing beyond noting the systematic use of murder, injury, and destruction or the threats of such acts toward achieving political ends is bound to lead to endless controversies.

—Walter Laqueur, Terrorism

Words differently arranged have a different meaning, and meanings differently arranged have different effects.

-Blaise Pascal, Pensées

Since 2001, defining terrorism has been a wide, growing field in attempts to establish a theoretical model of "what terrorism is." Academics compare attempts to develop this model to chasing a chimera or entering a Bermuda Triangle of definitions. ${ }^{2}$ The lack of consensus on a definition is a major hindrance to its study and theory development. ${ }^{3}$ Most definitions of terrorism focus on the actions of individuals or groups, and attempt to prohibit specific behaviors. The focus on behavior as a basis to define terrorism causes the labeling and targeting of groups without understanding the purpose of the behaviors.

This monograph does not focus on defining terrorism overall as there are already numerous books on the subject, which often seem to fall short of that goal. In response to Alex Schmid's survey on terrorism definitions, Jeffrey Simon posed two questions on definitions of terrorism: What is terrorism, and who is a terrorist $?^{4} \mathrm{He}$ notes that bureaucratic perspective and responsibility are key in the development of definitions, and are the reason many governments have internal definitions of terrorism. ${ }^{5}$

${ }^{1}$ Dipak K. Gupta, Understanding Terrorism and Political Violence: The Life Cycle of Birth, Growth, Transformation, and Demise (London: Routledge, 2008), 2. Gupta notes that the number of books with the word "terrorism" in the title published between 2000 and 2007 was more than ten times the total number in the previous six decades. The total number as of 2007 was almost 11,000, and it stands to reason that the rate of expansion has not slowed in the seven years since.

${ }^{2}$ Alex Schmid, ed., The Routledge Handbook of Terrorism Research (Routledge Handbooks), Reprint ed. (New York, NY: Routledge, 2013), 42.

${ }^{3}$ Ibid., 43.

${ }^{4}$ Ibid., 44.

${ }^{5}$ Schmid, 44. 
The responsibility of the Department of State $(\mathrm{DoS})$ is to use a statutory definition of terrorism to designate international "terrorist organizations" across a designation framework. This framework uses the perspective of a listed group's threat to U.S. citizens or its national security, consisting of national defense, foreign relations, or economic interests. ${ }^{6}$ The difficulty in researching the U.S. Government's reasoning for listing particular international terrorists is that the designation process is not required to answer "why" groups are designated, only that they are designated.

Depending on the source, there are up to 4,000 documented violent groups that espouse or use terrorism as a tactic. ${ }^{7}$ The United States cannot and should not list all of these groups as international terrorist organizations due to their sheer numbers, which would make designation meaningless if it is allinclusive. There are 57 groups currently named to the Foreign Terrorist Organization (FTO) list since its inception in 1997, with only nine groups delisted in the same period. ${ }^{8}$ A list of all groups designated as FTOs as of 17 March 2014 is in Appendix A as Table 1. A review in Chapter 6 of the 2012 Country Reports on Terrorism reveals that some, but not all, of the listed groups have posed a direct threat to U.S. national security. Some designated groups, such as Al-Qaida and its affiliates, pose an obvious threat to U.S. national security. ${ }^{9}$ Other groups, such as the Continuity Irish Republican Army and Jundallah, which are violent groups that espouse terrorist tactics, do not seem to directly connect to U.S. national interests. ${ }^{10}$ Utilizing the Specially Designated National (SDN) search function on the Treasury Department's Office of Foreign Asset Control (OFAC) website, 245 “entities” are designated as Specially Designated Global Terrorists (SDGT) or Specially Designated Terrorists (SDT). ${ }^{11}$ Many of the listed

${ }^{6}$ U.S. Department of State, "Foreign Terrorist Organizations," http://www.state.gov/j/ct/rls/other/ des/123085.htm (accessed 14 March 2014).

${ }^{7}$ Schmid, 343-348.

${ }^{8}$ Department of State, "Foreign Terrorist Organizations."

${ }^{9}$ U.S. Department of State, Bureau of Counterterrorism, Country Reports on Terrorism 2012 (Washington, DC: 2013), 278-283.

${ }^{10}$ Ibid., 267, 253-254.

${ }^{11}$ Office of Foreign Asset Control, "SDN Search," http://sdnsearch.ofac.treas.gov/default.aspx (accessed 17 
entities are under several sanction programs in addition to SDGT, and many are business organizations apparently linked to terrorism. Results from this search are in Appendix A as Table 1. The lack of apparent consistency in designating terrorist organizations opens the United States to charges of hypocrisy in applying the designation, and lessens the meaning of the designation. ${ }^{12}$ These hypocrisy charges are both domestic and international, focusing on the lack of transparency in the process and the interests of the parties involved. The case study of the Mujahedin-e Khalq is a good example of this, where Iran decried the MeK's delisting, while public figures like GEN(R) Hugh Shelton question the reason for listing the MeK in the first place. ${ }^{13}$

Determining who is a threat to a government and its citizens is a difficult proposition. This is especially true in the realm of terrorism, in which actions are the primary measurement used to determine classification. Attempting to define a group by its behaviors or actions they adopt to fight against a government can lead to a limited understanding, as their method does not indicate their specific purpose. Classification of a group as "terrorist" does not consider its strategy, doctrine, or mission, which is essential for understanding who they actually are. This leads the government to a focus on tactics that lacks understanding of how a group sees itself in relation to its adversaries and its allies, and the purpose of the group's actions.

While officially labeling groups enables operations to counter them, the efficacy of the designation is important to ensure counterterrorism efforts target the group in an effective manner. Applying the efficacy to the definition is important to the designation of terrorist organizations because it

March 2014).

${ }^{12}$ Hugh Shelton, "Ending Hypocrisy of Terrorist Designation," The Washington Times, 13 October 2011, http://www.washingtontimes.com/news/2011/oct/13/ending-hypocrisy-of-terrorist-designation/ (accessed 13 March 2014).

${ }^{13}$ Yeganeh Torbati, "Iran Condemns U.S. Removal of MEK from Terrorist List," Reuters, 26 September 2012, http://www.reuters.com/article/2012/09/26/us-iran-usa-idUSBRE88P0B420120926 (accessed 31 March 2014); Shelton, "Ending Hypocrisy." 
ensures achieving the desired effects. ${ }^{14}$ Applying effectiveness to the utilization of organization designation allows the label to achieve the intended effects. ${ }^{15}$ The lack of clarity and utility in the current definition and discretion in applying sanctions against these groups can create confusion and lack of consensus in using the terrorist label. The lack of a consensus in designating terrorist organizations lessens the credibility and meaning of the designation, opening the United States to hypocrisy. This leads to the research question: Is the current U.S. designation framework effective in identifying terrorist groups while mitigating negative effects on military and diplomatic operations?

Examination of the U.S. sanctions framework will demonstrate how excessive discretion in designating groups as "terrorist organizations," while allowing political flexibility, becomes a diplomatic negotiating tool, reducing the legitimacy of the designation. This subjective framework use is enabled by a vague statutory definition of terrorism that is focused on terrorism as a behavior, not countering the purpose of terrorist groups. The United States previously designated groups as terrorist organizations, using broad discretion and vague definition, and causing diplomatic embarrassment and confusion in military operations. This will prove the thesis that the United States is inconsistent in designating terrorist organizations because of wide discretion in applying designation labels, using a vague definition of terrorism that focuses group behavior, not their stated purpose. Failing to achieve an accurate classification and targeting of threat group or engaging friendly groups leads to wasted diplomatic and military efforts at strategic and operational levels.

This monograph will use three forms of references. Primary sources will utilize United States Code (U.S.C.), United States District Court cases, official government publications, and "frequently asked questions" produced by the DoS and other government agencies. They will provide current definitions

\footnotetext{
${ }^{14}$ Webster's dictionary defines efficacy as "the power to produce a desired result or effect." MerriamWebster Dictionary, s.v. "efficacy," http://www.merriam-webster.com/dictionary/efficacy (accessed 13 March 2014).

${ }^{15}$ Webster's dictionary defines effective as "producing a result that is wanted; having an intended effect." Merriam-Webster Dictionary, s.v. "effective," http://www.merriam-webster.com/dictionary/effective (accessed 13 March 2014.
} 
and designation framework information for analysis. Government documents are from official sources to ensure validity, accuracy, and authenticity. Secondary sources include scholarly books, journals, and professional research writings and provide academic analysis, input, and reinforcement to argument. Verification of information uses similar references for validation.

The literature review addresses the challenge academics have encountered in defining terrorism and the current government definitions applicable to the discussion. The review also outlines the current U.S. framework for designating terrorist groups and highlights its limited academic discussion. Section One examines the United States' vague wording in its definition of terrorism in relation to academic models, and proposes changes that increase clarity in the designation. Section Two will assess the impact of a vague definition on the overlapping structure of the sanctions framework, which allows excessive discretion in designating terrorist organizations. The effects of discretionary designation is demonstrated in Section Three, which will use case studies of U.S. Government interaction with the Communist Part of Nepal (Maoist) (CPN(M)) and the Mujahedin-e Khalq (MeK) to demonstrate the consequences of political influence. Finally, the conclusion summarizes the findings and proposes changes to reduce inconsistency. 


\section{LITERATURE REVIEW}

Developing an understanding of an effective definition of terrorism is a long and frustrating process because most literature focuses on the concept of terrorist acts and their sources, without thoroughly defining it first. This distinction is important because governments must establish a sound definition of terrorism in order to begin dealing with its sources. The expanse of material on terrorism is indicated by the increase of the number of books with "terrorism" in their title published between 2000 and 2007, which rose more than ten times the total number of books in the previous six decades. There is an overwhelming amount of research on trying to frame and identify the concept of terrorism, but significant gaps remain in the development of a theoretical model for the definition of terrorism. ${ }^{16}$

\section{Continuous Difficulty in Defining Terrorism}

Defining terrorism has not been simple; it has gained little consensus due to the wide variation of viewpoints on the subject. Authors from a number of academic disciplines have produced studies and surveys, indicating the countless debates and frustration of the pursuit. Alex Schmid conducted a landmark academic survey, and identified more than 250 academic, governmental, and intergovernmental definitions, signifying the proliferation of definitions throughout history without a consensus on the action. ${ }^{17}$

Several academic publications and theories reference academic discussions of the definition of terrorism. Their in-depth experience, publications, and analysis of U.S. terrorist designation frameworks contributed greatly to the research of this monograph. These academic works provide the backbone of the literature review and analysis of the U.S. terrorism designation framework.

Dr. Alex Schmid is the Director of the Terrorism Research Initiative, a network of scholars who conduct collaborative research. He has authored and edited more than 150 reports and publications, and is

\footnotetext{
${ }^{16}$ Gupta, 2.

${ }^{17}$ Schmid, 44.
} 
responsible for several landmark surveys that collected input from across academia to establish elements of an academic consensus definition of terrorism. ${ }^{18}$ Dr. Boaz Ganor is the Ronald Lauder Chair for Counter-Terrorism and Deputy Dean at the Lauder School of Government at the Interdisciplinary Center (IDC) in Herzliya, Israel. He has published and edited numerous articles and books on terrorism and counter-terrorism, with his most well known book The Counter-Terrorism Puzzle-A Guide for Decision Makers used as a textbook in universities worldwide. ${ }^{19}$ Dr. Bruce Hoffman is currently the Director of the Center for Security Studies at Georgetown University's Edmund A. Walsh School of Foreign Service in Washington D.C. He published his highly acclaimed book, Inside Terrorism, in 2006 and the Washington Post has described it as the "best one volume introduction to the phenomenon". ${ }^{20}$ Dr. Dipak K. Gupta is a Distinguished Professor in Political Science at San Diego State University and was the Fred J. Hansen Professor of Peace Studies from 1998-2001 and 2004-2011. He has authored nine books and published over 100 articles in scholar journals and research monographs. ${ }^{21}$ Dr. Paul Pillar is core research member of the Security Studies Program at Georgetown University in Washington, D.C. His book Terrorism and U.S. Foreign Policy is a Washington Post bestseller. ${ }^{22}$

The primary factor identified in the relevant literature is the lack of consensus in constructing a contextual definition of terrorism. The requirement for context can be broken down further into two factors: The context of the act from the victim's point of view, and the purpose of the act considering the intent of the actor. Several definitions of terrorism contain similar concepts that address both context and purpose. Discussion of the differences between the statutory definitions used by the DoS and Department

\footnotetext{
${ }^{18}$ Schmid, xii.
}

${ }^{19}$ International Institute of Counter-Terrorism, “Dr. Boaz Ganor,” http://www.ict.org.il/Biographies/ DrBoazGanor/tabid/152/Default.aspx (accessed 19 March 2014).

${ }^{20}$ Georgetown University Center for Peace and Security Studies, "Bruce Hoffman," Georgetown University, http://explore.georgetown.edu/people/brh6/ (accessed 19 March 2014).

${ }^{21}$ San Diego State University Department of Political Science, "Dr. Dipak Gupta, Political Science, ” San Diego State University, http://www-rohan.sdsu.edu/ dgupta (accessed 19 March 2014).

${ }^{22}$ Georgetown University Center for Security Studies, "Paul R Pillar," Georgetown University, http://explore.georgetown.edu/people/prp8/ (accessed 19 March 2014). 
of Defense (DoD) provide examples of how cabinet-level Departments address these two factors. The literature review will add context to the monograph by outlining the statutory framework for labeling groups as terrorist and the resulting effect of such a designation. These topics will provide an overview on creating a common definition of terrorism, the construction of the United States definition, and the impact of being designated as a terrorist group. These are three critical considerations when determining the effectiveness of the United States definition of terrorism.

\section{$\underline{\text { Academic Definition in Two Parts }}$}

Schmid recognizes that, as a manmade construct, there is no intrinsic definition of terrorism, and relies on the point of view of the target and the actor. ${ }^{23}$ Hoffman and Schmid recognize that groups who conduct terrorism rarely see themselves as "terrorists," instead preferring names involving freedom, liberation, and self-defense. ${ }^{24}$ Groups labeled "terrorists" see themselves as "reluctant warriors," who lack alternatives to violence to counter a repressive government, rival ethnic groups, or an unresponsive international political framework. Such groups resort to violence against civilians, only because they lack the strength in arms to confront military forces directly. ${ }^{25}$ Academic discussion points to two debated features of what "terrorism" is: defining "who" is a target of terrorism, and establishing the purpose of the act. Academics attempt to address these issues by establishing models of observable characteristics of terrorism definitions.

\section{Defining Noncombatants and the Purpose of the Act}

Discussion about who is a target of terrorism focuses on developing the concept of noncombatants. The debate centers on whether only civilians can be non-combatants, or if this can also include military personnel in a peacetime status. Hoffman, Schmid, and Pillar provide examples, such as

${ }^{23}$ Schmid, 40 . Schmid, 40.

${ }^{24}$ Bruce Hoffman, Inside Terrorism, rev ed. (New York, NY: Columbia University Press, 2006), 21; Alex

\footnotetext{
${ }^{25}$ Hoffman, $22-23$.
} 
the bombing at Khobar Towers or the attack against the USS Cole, to debate the required context whether military personnel can possess non-combatant status or, if by the nature of their profession, are always considered combatants. ${ }^{26}$ This contrasts to the concept that only civilians can be non-combatants and targets of terrorism. Ganor argues that military personnel are always legitimate targets of terrorists because of their profession, regardless of whether their duty status involves being armed or in a combat zone. ${ }^{27}$ Context is a required factor when developing a noncombatant definition because the perpetrator and target both possess extremely different viewpoints of a terrorist act. In the case of the opposing viewpoints above, if military forces are always seen as combatants, then it could be argued that a nation that raises a military force is always in combat. This contrasts to military forces only being combatants in an identified combat zone, which creates an excessively wide definition of noncombatants.

The purpose of terrorism invites discussion when developing a definition. A common aspect of Ganor, Schmid, and Hoffman's discussion of definitions is the use of force or violence, but the literature does not develop consensus on the purpose of the violence. ${ }^{28}$ Although terrorist acts are generally a form of crime, they possess a psychological aspect of spreading fear through a criminal activity. Hoffman and Ganor separate crime from terrorism as an important distinction, because criminal violence lacks the enduring psychological effect that is inherent in terrorism. ${ }^{29}$ Ganor states that non-violent activities such as protests and demonstrations are not terrorism, because they lack the use of force. ${ }^{30}$ Ganor and Hoffman suggest the primary motivation for violence should be limited to political influence, as alternate reasons

${ }^{26}$ Hoffman 32; Schmid, 46-47; Paul R. Pillar, Terrorism and U.S. Foreign Policy, pbk. ed. (Washington, DC: Brookings Institution Press, 2003), 14. Terrorists attacked Khobar Towers in 1996 with a suicide truck bomb; terrorists attacked the USS Cole with a small boat loaded with explosives while in harbor at Aden, Yemen in 2000. Both incidents were during "peacetime."

${ }^{27}$ Boaz Ganor, The Counter-Terrorism Puzzle: A Guide for Decision Makers (New Brunswick, NJ: Transaction Publishers, 2005), 23.

${ }^{28}$ Boaz Ganor, “Defining Terrorism: Is One Man’s Terrorist Another Man's Freedom Fighter?” Police Practice and Research 3, no. 4, (2002): 294; Alex Schmid, 39; Hoffman, 36.

${ }^{29}$ Hoffman, 36; Ganor, “Defining Terrorism,” 294.

${ }^{30}$ Ganor, “Defining Terrorism,” 294. 
can confuse analysis of the act. ${ }^{31}$ Schmid, Hoffman, and Ganor claim that specific motivations, such as religious or ecological terrorism, are irrelevant because resorting to common terrorist practices to coerce or influence still fall under creating or maintaining political change. ${ }^{32}$ The literature describes the purpose of the terrorist act as using violence to coerce a population or influencing the political process through fear, but does not come to a consensus on the details of each characteristic.

\section{Required Characteristics of the Definition}

Several theorists have identified the concepts or principles of the United States' statutory definition of terrorism. As Boaz Ganor questions the cliché, “one man's terrorist is another man's freedom fighter," he identifies three critical characteristics that define terrorism: a violent act, a political purpose, and the targeting of noncombatants. ${ }^{33} \mathrm{He}$ labels the violent act as the essence of the action, because nonviolent acts cannot be terrorism, assumedly because it does not involve fear. ${ }^{34} \mathrm{He}$ states the goal of the terrorist act is to achieve a political effect, whether overthrow of the government or revising a political, social, or religious norm. He labels terrorism without a political purpose is, at most, a criminal act. ${ }^{35}$ Ganor finally asserts that the target of the damage must be civilian, as this distinguishes it from guerrilla warfare directed against a government. ${ }^{36}$

Although Ganor does not include the requirement for identification of the actor in his definitional characteristics, he acknowledges that nations who attack civilians are not committing terrorism. Such nations are committing crimes against humanity during peacetime, or violating the law of war during

\footnotetext{
${ }^{31}$ Ganor, "Defining Terrorism," 294; Hoffman, 37.

${ }^{32}$ Schmid, 66 and 178; Hoffman, 88; Ganor, The Counter-Terrorism Puzzle, 17.

${ }^{33}$ Ganor, The Counter-Terrorism Puzzle, 17.

${ }^{34}$ Ibid.

${ }^{35}$ Ibid.

${ }^{36} \mathrm{Ibid}$.
} 
combat, thus separating nations from non-state actors. ${ }^{37}$ Ganor also says the most important distinction between terrorists and freedom fighters is their selection of targets. He asserts that when a group uses violence to achieve a political purpose and specifically targets civilians, they are terrorists, regardless of their previous targets. ${ }^{38}$ This critical element reveals the characterization of the group based on their act, which relies on leveraging the fear of the populace through specific targeting, not collateral or incidental injury.

Ganor's characteristics are similar to the scholarly analysis by Dipak Gupta, who identified four factors contained in the DoS definition: the violence of the act, a non-state actor, a non-combatant target, and political motivation. ${ }^{39}$ Gupta adds that the focus of the definition is not on the "lone wolf" terrorists, giving the example of Ted Kaczynski, because he is primarily interested in the life-cycle of terrorist organizations, as is this monograph. ${ }^{40}$ Gupta agrees with Ganor in that violence is required for terrorism, as nonviolent acts or a lack of threat of violence do not qualify. ${ }^{41}$ The second criteria he identifies is that only non-state actors conduct terrorism, which excludes the actions of both dictators and military forces, essentially excluding the largest source of civilian death - government. ${ }^{42}$ Gupta's third criteria, relating to the DoS definition, focuses on the selection of targets, and specifically questions whether "noncombatant" includes military personnel not in a wartime status, such as attacks on the USS Cole, or Flight \#77, which crashed into the Pentagon on 11 September $2001 .{ }^{43} \mathrm{He}$ identifies this as the most arbitrary criteria, because labeling one attack as terrorism and another as guerrilla action may serve political

\footnotetext{
${ }^{37}$ Ganor, The Counter-Terrorism Puzzle, 18-19.

${ }^{38}$ Ganor, "Defining Terrorism," 288.

${ }^{39}$ Gupta, 8 .

${ }^{40}$ Ibid., 9.

${ }^{41}$ Ibid., 8 .

${ }^{42}$ Ibid., 9.

${ }^{43}$ Ibid.
} 
purposes, but do not add to the political discourse. ${ }^{44} \mathrm{He}$ calls the requirement for political aim the most important criteria, since it distinguishes between terrorists using violence for a "higher good" and a criminal gang's motivation that rests with the group. ${ }^{45}$

Pillar also identifies four elements in the DoS definition: premeditation, political motivation, noncombatant targets, and subnational agents. ${ }^{46}$ Although his elements are similar, Pillar differs from Gupta in the analysis of the concepts. His biggest difference is the focus on premeditation, where a terrorist act must have intent and a prior decision for commission, which excludes impulse and accidents. ${ }^{47}$ His second element, political motivation, is similar to Ganor and Gupta in requiring a focus on "macro concerns" about changing a larger order, which excludes the monetary motivation of criminal violence. ${ }^{48}$ Pillar classifies noncombatants as including military personnel in a noncombat or unarmed status, such as the example of the attack on Khobar Towers or the U.S. Marine barracks in Beirut. ${ }^{49}$ Pillar distinguishes the acts of war by nations from subnational groups in his final element, and acknowledges that "lone wolf" terrorists groups can exist, in that they can cause terror by meeting all of the previous elements. ${ }^{50}$ At the end of his discussion about the definition, he adds that the threat of terrorist attack is terrorism as well, addressing the fear component indirectly. ${ }^{51}$

\section{Conclusions About Definitional Elements}

In order to classify an act as terrorism, the consensus between these three academics analyses is that a violent act must occur with a political and psychological purpose against noncombatants. Terrorists

\footnotetext{
${ }^{44}$ Gupta, 9 .

${ }^{45}$ Ibid., 10.

${ }^{46}$ Pillar, 13.

${ }^{47}$ Ibid.

${ }^{48}$ Ibid., 14.

${ }^{49}$ Ibid.

${ }^{50}$ Ibid.

${ }^{51}$ Ibid.
} 
utilize violence as a means to reach their end state of political influence through fear or coercion. Without violence, there is no fear or coercion induced, and thus no terrorism. If a group is using violence, but is not attempting to achieve a political purpose, they are simply committing a criminal act. There is agreement between models on the requirement for noncombatants, but there is dissent on who is a noncombatant and under what circumstances.

\section{Government Definitions of Terrorism}

In his study, Schmid identified more than 20 domestic and international terrorism definitions by the United States Government alone. ${ }^{52}$ These definitions were primarily at the cabinet and agency level, and focus on the internal mission of the organization. This is apparent from the word choice within each definition, which clearly orients on the organization's mission. With the exception of the DoS, which uses a statutory definition, the Departments of Defense, Treasury, Homeland Security, and Justice all have distinctly different non-statutory definitions. This literature review will examine only the DoS and DoD definitions to highlight the differences for further discussion. Each respective department's definition reflects their understandings of what terrorism is, and how they attempt to counter it.

Examination of the United States' terrorism definition must start with examination of the legal code, which contains the statutory definition used by the DoS to designate terrorist organizations. The statutory definition is contained in 22 U.S.C. $§ 2656 \mathrm{f}(\mathrm{d})$, and was conceived in its current form in the Foreign Relations Authorization Act (FRAA) of Fiscal Year 1988-1989. ${ }^{53}$ This definition is found throughout official United States documents when designating who constitutes a "terrorist." The DoS is the primary agency involved in the designation of terrorist organizations, and utilizes the statutory

\footnotetext{
${ }^{52}$ Schmid, 44.
}

${ }^{53}$ Office of the Coordinator for Counterterrorism, "Fact Sheet, Foreign Relations Authorization Act, Fiscal Years 1988 and 1989: Terrorism Definition," 8 April 2008, http://2001-2009.state.gov/s/ct/rls/fs/08/103401.htm (accessed 12 December 2013). 
definition of terrorism, which is, "premeditated, political motivated violence perpetuated against noncombatant targets by subnational groups or clandestine agents." 54

Schmid asserts in his survey that the statutory definition has changed no less than eight times between 1982 and 2006, with the final change removing the purpose statement on the end of the definition, "usually intended to influence an audience." 55 This is not correct, as the definition did not exist until Congress enacted the FRAA of 1988-1989, making it very difficult for Schmid to demonstrate its change prior to its inception. The "removed" part of the definition Schmid cites, originally existed in the 1995 Patterns of Global Terrorism, where the definition in the introduction by the DoS insinuated that "usually intended to influence an audience" was part of 22 U.S.C. $§ 2656 f(d) .{ }^{56}$ The DoS did not correct the error in its representation of the statutory definition until 2004 when the title of the document changed to Country Reports on Terrorism. ${ }^{57}$. This effect of this misleading statement is found throughout the academic discussion on terrorism because several authors refer to the inaccurate version of the definition. This gives the impression that Congress removed the purpose of the statutory definition of terrorism, when it never officially existed. ${ }^{58}$

Pillar, Schmid, Hoffman, Ganor, and Gupta consider the statutory definition as a starting point to debate the composition requirements of terrorism definitions, although not all agree on the elements it contains. ${ }^{59}$ Pillar identifies four elements contained in the United States' statutory definition:

${ }^{54}$ Foreign Relations Authorization Act, Fiscal Years 1988 and 1989, Public Law 100-204, § 140, U.S. Statutes at Large 101 (1987): 1347-49, codified at U.S. Code 22 (2012), § 2656f(d)(2).

${ }^{55}$ Schmid, 44.

${ }^{56}$ Office of the Coordinator for Counterterrorism, "Introduction Global Patterns of Terrorism 1996," http://www.state.gov/www/global/terrorism/1996Report/1996index.html (accessed 15 March 2014).

${ }^{57}$ Office of the Coordinator for Counterterrorism, "Chapter 1 Legislative Requirements and Key Terms, Country Reports on Terrorism 2004,” http://www.state.gov/j/ct/rls/crt/45323.htm (accessed 15 March 2014).

${ }^{58}$ Intelligence Reform and Terrorism Prevention Act of 2004, Public Law 108-458, § 7102, U.S. Statutes at Large 118 (2004): 3777-78, codified at U.S. Code 22 (2012), § 2656f. The only change found by the author during research of the statutory definition in United States Code was that in 2004, the "and" was removed from 22 U.S.C § $2656 f(d)(2)$.

${ }^{59}$ Pillar, 13; Schmid, 44; Hoffman, 32; Ganor, The Counter-Terrorism Puzzle, 23; Gupta, 8. 
premeditation, political motivation, targeting of noncombatants and perpetrators as either subnational groups or clandestine agents. ${ }^{60}$ Gupta's analysis of the statutory definition differs in that he focuses on the violence aspect of the DoS definition, not the premeditation of the act. ${ }^{61}$ The key term "noncombatant" in the DoS definition is not defined in 22 U.S.C. $§ 2656 \mathrm{f}(\mathrm{d})$, but is interpreted in the Country Reports on Terrorism 2012 as including civilians as well as military personnel, armed or not, who are not in a war zone or warlike setting. The only exclusion made is armed military personnel in a combat zone, such as Afghanistan in 2012. ${ }^{62}$

Cabinet-level departments and their subordinate agencies commonly have separate definitions that are reflective of their role in countering terrorism and capability to do so. The definition of terrorism utilized by the DoD in Joint Publication 1-02 is, "The unlawful use of violence or threat of violence to instill fear and coerce governments or societies. Terrorism is often motivated by religious, political, or other ideological beliefs and committed in the pursuit of goals that are usually political." ${ }^{63}$

Hoffman argues that this definition is more complete than the statutory definition, although it does not distinguish between targeting noncombatants and military forces. ${ }^{64}$ This definition also contrasts with the DoS definition in that it does not recognize who the agents are that conduct terrorism. In contrast, the DoD definition identifies some root motivations for "the unlawful use of violence," and the psychological purpose of terrorism for coercive purposes. The definition also recognizes the social aspect of terrorism and that threats of violence may fulfill the psychological purpose of terrorism without actual violence. ${ }^{65}$ Academics have not examined the DoD definition to the extent of the statutory definition, but

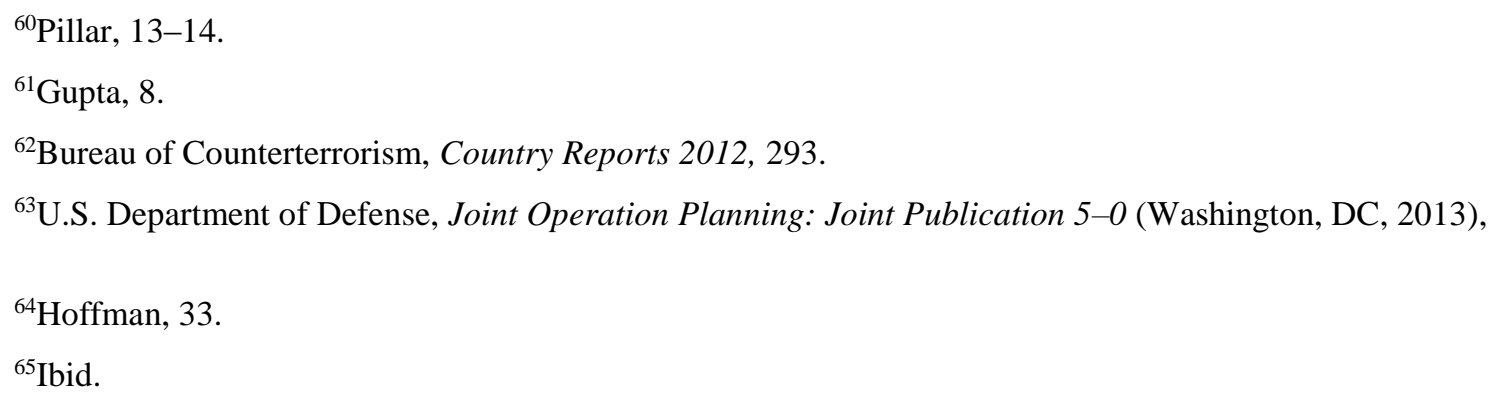


this definition is critical to how the United States utilizes military force to interact with designated terrorist groups.

There is no consensus among academics on the construction of a definition of terrorism due to the influence of context and purpose on definitional requirements. Several academics developed required attributes of a definition of terrorism, but the requirement of the defining agency to determine the quality of those attributes remains. Cabinet level definitions of terrorism are, by design, focused on the mission of the organization in order to guide mission accomplishment in their respective terrorism function. As will be examined in the framework, 18 U.S.C. $§ 2339 \mathrm{~B}$ prevents diplomatic and military representatives from interacting with groups and individuals on are on the SDN list.

\section{$\underline{\text { U.S. Government Terrorism Framework }}$}

In conducting research for this monograph, few books give more than a passing mention to the United States' designation framework with only a couple of articles discussing it in detail. The United States maintains the SDN list as a consolidation of all groups or individuals that have financial or travel restrictions. This consolidated list provides a single resource for accessing currently sanctioned entities. ${ }^{66}$ Within the SDN list, there are fourteen different designations of sanctions, four of which pertain directly to terrorism. Designation as a SDT or SDGT allows for the blocking of financial transactions through U.S. financial institutions or by U.S. nationals ${ }^{67}$ The SDT and SDGT lists are strictly financial sanctions maintained by the Treasury Department. Both of these classifications, in addition to the FTO list and other narcotic and criminal-based lists, are contained under the SDN list, which is the master list of sanctions against foreign groups and individuals. ${ }^{68}$ The DoS may designate groups on multiple lists concurrently, depending on the purpose of the sanctions and the ability to support the required. A

\footnotetext{
${ }^{66}$ Audrey Kurth Cronin, "The 'FTO List"” and Congress: Sanctioning Designated Foreign Terrorist Organizations.” No. RL32120. (Congressional Research Service Report for Congress, 2003), 5.

${ }^{67}$ Ibid., 4.

${ }^{68}$ Ibid., 5.
} 
description of the FTO, SDT, SDGT, and TEL designations along with the prohibitions they place on U.S. citizens explains the United States' framework.

The FTO list is the most widely published of the terrorism-related SDN lists due to the very public announcement of groups placed on the list. ${ }^{69}$ The Antiterrorism and Effective Death Penalty Act established the category in 1996, which amended 8 U.S.C. to allow the Secretary of State to designate FTOs. ${ }^{70}$ An organization is listed as a FTO when it is designated by the Secretary of State under 8 U.S.C. $\S 1189(\mathrm{a})(1)$ if the organization,

(1) is a foreign organization;

(2) the organization engages in terrorist activity (as defined in section 1182(a)(3)(B) of this title or terrorism (as defined in section 2656(d)(2) of title 22), or retains the capability and intent to engage in terrorist activity or terrorism); and

(3) the terrorist activity or terrorism of the organization threatens the security of United States nationals or the national security of the United States. ${ }^{71}$

"National security" of the United States is defined under 8 U.S.C. $§ 1189$ (d) as "national defense, foreign relations or economic interests." ${ }^{, 72}$ A FTO designation is the most punitive category on the Specially Designation National list, and must meet the strictest review standards of any "terrorism" designation. Once a FTO is designated as such, they may not receive any support, resources, or training from U.S. nationals or persons subject to the prohibition; may not be admitted to the United States and may be deported; and must have all financial transactions blocked by U.S. based financial institutions. ${ }^{73}$ The groups may challenge their designation as a FTO in court every two years. ${ }^{74}$ Designation is in

${ }^{69}$ Cronin, “The 'FTO List,"” 2.

${ }^{70}$ Ibid.

${ }^{71}$ Department of State, "Foreign Terrorist Organizations."

${ }^{72}$ Antiterrorism and Effective Death Penalty Act of 1996, Public Law 104-132, § 302, U.S. Statutes at Large 110 (1996): 1248-50, codified at U.S. Code 8 (2012), § 1189(d).

${ }^{73}$ Department of State, "Foreign Terrorist Organizations."

${ }^{74} \mathrm{Ibid}$. 
cooperation with the Department of Justice and the Treasury Department to establish proof of terrorism activity and coordinate sanctions.

President Clinton established the SDT list in 1995 under the International Emergency Economic Powers Act (IEEPA) as Executive Order (E.O.) 12947, aimed specifically at financially blocking groups and individuals that were threatening to disrupt the Middle East Peace Process. ${ }^{75}$ The justification for this list was that the Middle East Peace Process was central to U.S. National Security; it blocked all U.S. assets, and prohibited all U.S. citizens from engaging in transactions with the listed parties. ${ }^{76}$ Addition to the list is not challengeable in court or appealable by the designated group and removal from the list is only upon decision by the Secretary of State or termination of the Executive Order. ${ }^{77}$ The SDT list was incorporated into the SDGT list after the 11 September 2001 attacks, to include the increased sanctions on supporting entities. ${ }^{78}$

President Bush established the SDGT list in 2001 as a response to the 9-11 attacks under the IEEPA. ${ }^{79}$ This list, written as E.O. 13224, blocks all properties and interests of listed groups, individuals, and supporting entities involved in 11 September 2001, or as designated by the Secretary of State. The SDGT list increases the application of sanctions to entities who support terrorism or terrorist activities, including nongovernmental organizations and individuals. ${ }^{80}$ The following excerpt from E.O. 13224 explains whom the Secretary of State has the power to designate:

(a) Foreign persons listed in the Annex to this order;

${ }^{75}$ Laura K. Donohue, The Cost of Counterterrorism: Power, Politics, and Liberty (Cambridge; Cambridge University Press, 2008), 148.

${ }^{76} \mathrm{Ibid}$.

${ }^{77}$ Cronin, "The 'FTO List,"” 4.

${ }^{78}$ Rensselaer Lee, “Terrorist Financing. The U.S. and International Response.” No. RL31658. (Congressional Research Service Report for Congress, 2002), 15.

${ }^{79}$ Donohue, 166.

${ }^{80}$ Ibid., 166-167. 
(b) Foreign persons determined by the Secretary of State, in consultation with the Secretary of the Treasury and the Attorney General, to have committed, or to pose a significant risk of committing, acts of terrorism that threaten the security of U.S. nationals or the national security, foreign policy, or economy of the United States;

(c) Persons determined by the Secretary of the Treasury, in consultation with the Secretary of State and the Attorney General, to be owned or controlled by, or to act for or on behalf of those persons listed in the Annex to this order or those persons determined to be subject to subsection 1(b), 1(c), or 1(d)(i) of this order;

(d) except as provided in section 5 of this order and after such consultation, if any, with foreign authorities as the Secretary of State, in consultation with the Secretary of the Treasury and the Attorney General, deems appropriate in the exercise of his discretion, persons determined by the Secretary of the Treasury, in consultation with the Secretary of State and the Attorney General;

(i) to assist in, sponsor, or provide financial, material, or technological support for, or financial or other services to or in support of, such acts of terrorism or those persons listed in the Annex to this order or determined to be subject to this order; or

(ii) to be otherwise associated with those persons listed in the Annex to this order or those persons determined to be subject to subsection 1(b), 1(c), or 1(d)(i) of this order. ${ }^{81}$

The order specifically listed Al Qaeda and its associated groups, and Osama bin Laden and his supporters, as well as other persons who pose a risk to national security, foreign policy, the economy, or U.S. Citizens. ${ }^{82}$ The SDGT list also gives the Secretary of the Treasury power to block the assets of any person acting on behalf of, providing sponsorship or materials to, or is otherwise determined to be associated with those currently on the list. ${ }^{83}$ This gives unprecedented power to freeze assets; and once assets of a designated group or individual are blocked, they become illegal to support financially or materially. ${ }^{84}$

${ }^{81}$ George W. Bush, Executive Order 13224, "Blocking Property and Prohibiting Transactions With Persons Who Commit, Threaten To Commit, or Support Terrorism," Federal Register 66, no. 186 (25 September 2001): 49079-49080.

${ }^{82}$ Donohue, 166.

${ }^{83}$ Ibid.

${ }^{84}$ Ibid. 
E.O. 13224 also gives the SDGT list its own definition of terrorism, which is separate and distinct from the statutory definition in 22 U.S.C. $§ 2656$. The definition of terrorism in E.O. 13224 is an activity, and includes the following:

(i) Involves a violent act or an act dangerous to human life, property, or infrastructure; and

(ii) Appears to be intended-

(A) To intimidate or coerce a civilian population;

(B) To influence the policy of a government by intimidation or coercion; or

(C) To affect the conduct of a government by mass destruction, assassination, kidnapping, or hostage taking. ${ }^{85}$

Having a separate definition of terrorism within E.O. 13224 allows the Secretaries of State and Treasury to designate without regard to the statutory definition. This distinction is very important to the discussion in Section Two of using separate definitions to designate terrorist groups as either an FTO or SDGT.

A group or individual placed on the Terrorist Exclusion List (TEL) may also be a SDT or SDGT under E.O.(s) 12947 and 13224, respectively. The TEL is solely for immigration purposes, and is pursuant to amendments made to 8 U.S.C. $\$ 1182$ under the USA Patriot Act in $2001 .{ }^{86}$ The DoS is responsible for the TEL with input from the Department of Justice. ${ }^{87}$ The TEL does not utilize a definition of "terrorism" to list individuals, instead deporting only foreign individuals associated with groups that engage in "terrorist activity" as defined in 8 U.S.C. $§ 1182(3)(B) .{ }^{88}$ The DoS website lists "terrorist activities” in 8 U.S.C. $§ 1182(3)(B)$ that consist of acts of high jacking, hostage taking, attacking diplomats, assassination, using weapons of mass destruction or threats, attempts or conspiracies to do so.$^{89}$ Only foreign nationals are on the TEL, resulting in their deportation or exclusion from entering the

\footnotetext{
${ }^{85}$ Bush, 49080.

${ }^{86}$ Cronin, "The 'FTO List,"” 5.

${ }^{87}$ Ibid., 5.

${ }^{88}$ Uniting and Strengthening America by Providing Appropriate Tools Required to Intercept and Obstruct Terrorism (USA PATRIOT ACT) Act of 2001, Public Law 107-56, § 411, U.S. Statutes at Large 115 (1996): 34548, codified at U.S. Code 8 (2012), § 1182(3)(B).

${ }^{89}$ U.S. Department of State, “Terrorist Exclusion List," http://www.state.gov/j/ct/rls/other/des/123086.htm
} (accessed 14 December 2013). 
United States without the ability to challenge their status in court. ${ }^{90}$ Cronin notes that the TEL is a broader standard than the FTO list, receiving less oversight while providing the same exclusionary effect. ${ }^{91}$

The laws governing penalties for terrorism are contained in 18 U.S.C. Chapter 113B, established by the Antiterrorism and Effective Death Penalty Act of 1996. Of specific interest to this discussion is 18 U.S.C. $§ 2339 \mathrm{~B}$, which prohibits the material support or resources to FTOs. This law forbids U.S. citizens from providing material support or resources to designated FTOs, or organizations that engage in terrorist activity or have previously engaged in terrorism. ${ }^{92}$ The key part of the unlawful conduct is the provision of material support or resources, which contains in its definition the prohibition of any “...training, expert advice or assistance...except medicine or religious materials." ${ }^{93}$ Training is defined as "instruction or teaching designed to impart a specific skill, as opposed to general knowledge." The final definition in the section explains the meaning of expert advice or assistance, meaning "advice or assistance derived from scientific, technical, or other specialized knowledge. ${ }^{94}$ Each of these prohibited activities restrict how U.S. citizens are allowed to interact with designated FTOs or SDGTs, which results in designations impacting the operational level of military and diplomatic actions.

The only relief for interacting with designated FTOs, SDTs, or SDGTs is applying for and receiving a waiver from the Office of Foreign Assets Control in the Department of Treasury. ${ }^{95}$ The general or specific licenses are required for "any transaction that might otherwise be prohibited." 96

${ }^{90}$ Cronin, “The 'FTO List,"” 5.

${ }^{91}$ Ibid.

${ }^{92}$ Antiterrorism and Effective Death Penalty Act of 1996, Public Law 104-132, § 303a, U.S. Statutes at Large 110 (1996): 1250-53, codified at U.S. Code 18 (2012), § 2339B(a)(1).

${ }^{93}$ Violent Crime Control and Law Enforcement Act of 1994, Public Law 103-322, § 120005, U.S. Statutes at Large 108 (1994): 2022-22, codified at U.S. Code 18 (2012), § 2339A(b)(1).

${ }^{94}$ Antiterrorism and Effective Death Penalty Act of 1996, Public Law 104-132, § 303a, U.S. Statutes at Large 110 (1996): 1250-53, codified at U.S. Code 18 (2012), § 2339B.

${ }^{95}$ U.S. Department of Treasury, "Office of Foreign Assets Control Frequently Asked Questions," http://www.treasury.gov/resource-center/faqs/Sanctions/Pages/answer.aspx\#60 (accessed 18 December 2013).

${ }^{96}$ U.S. Department of Treasury, "OFAC FAQ." 
General licenses allow an entire class of people to conduct a specific transaction, eliminating the need for a specific license for each transaction. Specific licenses authorize an individual or entity to conduct a specific transaction with a SDN as outlined within the license. ${ }^{97}$ License requirements apply to all U.S. nationals, including diplomatic and military personnel on government-assigned duties. This requirement can place diplomats and military personnel in an awkward situation when a listed agent or group comes into power, and prevents representatives of the United States from providing any assistance. Members of non-governmental organizations are also subject to the prohibition if they are U.S. nationals, preventing their access to clients as in the case of Holder v. Humanitarian Law Project (2010), which prevented lawyers from communicating with their PKK and LTTE clients during a challenge against their FTO status. ${ }^{98}$ This policy places groups attempting to challenge their designation in a situation where they are unable to coordinate their challenge with their lawyers, weakening their argument, and their ability to build a case.

The terrorism framework is comprised of several designations that range in severity of sanctions, and scrutiny of the facts of designation. This system of designations provides several options for naming terrorist organizations with limited ability to challenge designation. The Secretary of State determines how groups are designated, and uses three criteria to determine a group's status. Limits placed on interaction with terrorist groups, while meant to prevent funding and support from the United States, also prevent official United States representatives from interacting with these groups on a military or diplomatic basis.

\section{Literature Review Summary}

This literature review provided an overview on the difficulty in constructing a common definition of terrorism, the composition of the United States definition, and the process of designating as a terrorist

\footnotetext{
${ }^{97}$ U.S. Department of Treasury, “OFAC FAQ."

${ }^{98}$ Holder v. Humanitarian Law Project, 561 US 16, 17 (2010).
} 
group. The primary factor of disagreement identified throughout is the contextual requirements in identifying what a terrorist act is, and consequently who is a terrorist. This contextual requirement discussed by the perception of the victim as well as the intent of the actor results in widely differing opinions with little consensus among academics and government. The statutory framework for labeling groups and individuals as "terrorist" is a result of decades of E.O.s, statutory amendment and reaction to events instead of a holistic review of definitional requirements. These topics are three critical considerations when determining the effectiveness of the United States framework for designating terrorist organizations with the current definition of terrorism. 


\section{ISSUES IN THE STATUTORY DEFINITION OF TERRORISM}

As discussed in the review of the literature, definitions of terrorism are constructions that are behavior-focused. The United States' statutory definition of terrorism focuses on the ambiguous nature of noncombatants and the contextual requirement of the event, creating vagueness in the definition and enabling a liberal application to otherwise non-terrorist acts. A terrorism definition that is independent of perspective is more efficacious in designating FTOs, and the United States must adapt its definition to meet this requirement. Chapter 2 covers the impact of utilizing separate definitions for designating FTOs and SDGTs because the U.S. Government uses different methods to establish the definitions. This chapter will also address the shortcomings of the United States' terrorism definition, which contributes to the lack of effectiveness in designating terrorist organizations. An alternative definition that merges the statutory definition with the DoD definition satisfies academic elements and uses a model to assist in labeling that will enable this requirement.

\section{$\underline{\text { Statutory Definition Issues }}$}

As a review, the statutory definition of terrorism as listed in 22 U.S.C. $§ 2656 \mathrm{f}(\mathrm{d})$ is “premeditated, political motivated violence perpetuated against noncombatant targets by subnational groups or clandestine agents." ${ }^{99}$ Schmid argues that the definition used by the DoS in 22 U.S.C. $\S$ $2656 f(d)$ focuses on the political "why" an act is conducted, completely ignoring that the purpose of terror tactics is to manipulate. ${ }^{100}$ The United States must develop and use a definition of terrorism that clearly follows common definitional elements, allowing for predictability in labeling acts as terrorist, which would reduce the pejorative and arbitrary use of the definition. The U.S. Government definition is not

${ }^{99}$ Foreign Relations Authorization Act, Fiscal Years 1988 and 1989, Public Law 100-204, § 140, U.S. Statutes at Large 101 (1987): 1347-49, codified at U.S. Code 22 (2012), § 2656f(d)(2).

\footnotetext{
${ }^{100}$ Schmid, 44.
} 
clear or specific, allowing for a rather subjective process of designating terror groups that wastes effort and resources by allowing over-designation that reduces legitimacy.

Writing in Toward a Grand Strategy Against Terrorism, Christopher Cavoli gives two reasons why inaccurate labeling is counterproductive: it confirms that the government lacks comprehension of its opponent, and muddies the waters when clarity is required to develop a distinction between the two methods of attack. ${ }^{101}$ This confirms what Schmid notes as one of the major issues with the DoS definition of terrorism, which is the interpretation of noncombatant targets in relation to the definition. ${ }^{102}$ Hoffman notes there is no focus on the psychological component of terrorism, meaning that it instead focuses on the behavior of the terrorists themselves. ${ }^{103} \mathrm{~A}$ clear, concise definition, independent from contextual considerations within the U.S. Government, would also synchronize efforts to counter terrorism by providing specific criteria to label the act as "terrorism." This prevents designation of groups for political purposes who are not a threat to commit "terrorism" against the United States, freeing resources to counter groups who actively use such tactics.

The statutory definition identifies the target of terrorism as noncombatants, but the statute does not reference what a noncombatant is. In The Country Reports on Terrorism 2012, the DoS defines noncombatants as "in addition to civilians, military personnel (whether or not armed or on duty) who are not deployed in a war zone or a war-like setting." The same document states that the noncombatant definition is only for use within the report, and does not reflect the views of the U.S. Government. ${ }^{104}$

There are several problems with the lack of officially defining "noncombatants." The first issue is that if only military members in a combat zone are combatants and therefore not targets of terrorism, then any attack by a group that is not against a fielded military force is terrorism. Ganor states that this

\footnotetext{
${ }^{101}$ Christopher G. Cavoli, Toward a Grand Strategy Against Terrorism, ed. Christopher C. Harmon, Andrew N. Pratt, and Sebastian, Contemporary Learning Series (New York: McGraw Hill Companies, 2011), 139.

${ }^{102}$ Schmid, 46.

${ }^{103}$ Hoffman, 32.

${ }^{104}$ Bureau of Counterterrorism, Country Reports 2012, 293.
} 
definition unacceptably broadens the scope of defining noncombatants to blur the lines between military forces and civilians. He used the attack against the USS Cole as an example of a terrorist group that surprised a military force, which distinguishes their actions from attacking a civilian building or structure. ${ }^{105}$ Ganor argues that only using "civilians" to define the target narrows the ethical norm to be in line with international standards that distinguish between war criminals and combatants. ${ }^{106}$ As Schmid notes, "what distinguishes a soldier from a war criminal is that a soldier makes this crucial distinction between combatants, non-combatants... and civilians. What distinguishes an insurgent freedom fighter from a terrorist should be no different." ${ }^{107}$ This distinction is not sufficient in the current framework because of distinct definitions enabling discretion in designation, allowing the United States to take action without regards to the impact on future operations.

In responses to Schmid's study, discussion on noncombatants as targets centers on the moral gray area created by a lack of distinction between military and security targets, and civilians. ${ }^{108}$ This indicates the issue is in attempting to use duty status of military and security forces to classify terrorism, where attackers do not distinguish between the duty statuses of Government forces. ${ }^{109}$ Ganor applies the moral argument to defining the target and classifying the group, explaining that when a group attacks civilians in the pursuit of their goals, the ends can never justify the means. Once a group intentionally attacks civilians, they become a terrorist organization according to an objective measure, and not the perception of the definer. ${ }^{110}$

The United States' definition encompasses all attacks, other than against military forces in a combat zone, as terrorism. This broad definition allows contextual manipulation of the definition to

\footnotetext{
${ }^{105}$ Ganor, The Counter-Terrorism Puzzle, 23.

${ }^{101}$ Ibid., 18.

${ }^{107}$ Schmid, 68.

${ }^{108}$ Ibid., 45.

${ }^{109}$ Ibid., 47.

${ }^{110}$ Ganor, "Defining Terrorism," 298.
} 
include or exclude acts based on subjective decisions, not objective methods of classification. In the current definition, as long as a group does not target a military unit in a combat zone, they are committing terrorism according to the definition of noncombatant used by the DoS. This equates attacks on military units not in a combat zone with attacks on common civilians as both being acts of terrorism.

Another issue with the United States' statutory definition of terrorism is that it is behaviorfocused, and that it does not consider the psychological purpose of terrorism. ${ }^{111}$ Ironically, utilizing the portion "usually intended to influence an audience," which academics assumed as a part of the original statutory definition partially addresses this issue. Schmid's survey analysis revealed that this addition would only address the purpose of terrorism in a vague, incomplete manner, requiring additional clarity to address the psychological effect. ${ }^{112}$ Relying on behavior allows for the manipulation of the definition to fit the context, instead of focusing on the intent of the group and the act by removing context from the situation. Ganor and Hoffman both identify fear as the purpose of a terrorism so that the terrorist can achieve a political end. They distinguish this from criminal acts because although criminals use the same types of violence to achieve their ends, they focus on material gains, not coercing political change. ${ }^{113}$ Curiously, Ganor, Gupta, and Pillar all omit the requirement of fear from their characteristics of a terrorism definition, lumping it in with the requirement for violence as a cause of fear. Schmid's survey revealed that more than half of the 109 definitions had that element, surpassed only by the inclusion of a political requirement and the use of force. ${ }^{114}$ According to Brian Jenkins, terrorism is "theater," emphasizing the effect that the threat or act of violence has on the public psyche. ${ }^{115}$ Additionally, a respondent to Schmid's survey notes, "the influence the audience is subjected to is achieved through

\footnotetext{
${ }^{111}$ Hoffman, 32.

${ }^{112}$ Schmid, 45.

${ }^{113}$ Ganor, The Counter-Terrorism Puzzle, 17; Hoffman, 36-37.

${ }^{114}$ Schmid, 74.

${ }^{115}$ Brian Michael Jenkins, Research Paper - California Seminar on Arms Control and Foreign Policy, vol. no. 48, International Terrorism: a New Mode of Conflict (Los Angeles, CA: Crescent Publications, 1975$), 16$.
} 
fear," an element that is not addressed in the current definition. ${ }^{116}$ Understanding that fear is a required purpose of terrorist acts reveals how a terrorist organization will act to accomplish that purpose. The U.S. statutory definition does not acknowledge the psychological purpose of terrorism, allowing interpretation of acts as terrorism without regard to their purpose, which directly contradicts the academic understanding of terrorism.

The statutory definition is deficient in two very important aspects that render the definition excessively vague, reducing predictability and hindering effective identification of terrorism. Using "noncombatant" to describe the target of terrorism is inadequate because there is not a United States statutory definition that adequately gives meaning to this word as part of the definition of terrorism. The DoS definition of noncombatant only excludes deployed, armed military forces in a combat setting, including all other targets as terrorism. ${ }^{117}$ The lack of purpose in the statutory definition allows labeling simple crimes as terrorism because there is no distinction between the material motivation of crime and psychological motivation of terrorism. These two deficiencies lead to the proposal of an alternative definition that capitalizes on the strengths of the DoD and statutory definitions, and meets academic guidelines for terrorism definitions.

\section{Alternative to the Statutory Definition}

The purpose in proposing an alternative definition is to show that the statutory requirements and academic elements of defining terrorism can be met, providing a clearer, more concise definition that requires less interpretation. This counters bureaucratic theory, in which Graham Allison asserts that organizations will make decisions to allow leeway in how they implement them, which the current statutory definition reflects. ${ }^{118}$ Key terms within the definitions - intentional, politically motivated, coerce

\footnotetext{
${ }^{116}$ Schmid, 45.

${ }^{117}$ Bureau of Counterterrorism, Country Reports 2012, 293.

${ }^{118}$ Raymond Tanter, Theory and Policy in International Relations, ed. Richard H. Ullman (Princeton, NJ: Princeton University Press, 1972), 53.
} 
and civilian -clearly delineate the criteria of terrorism to prevent the possibility of word interpretation that creates a lack of clarity. Providing specified definitions to these key words allows for clarification, and prevents definition creep that would result in mislabeling acts as "terrorism" when they are actually guerrilla or criminal violence.

\section{Combining Cabinet Definitions}

To make the United States' statutory definition more effective to identify terrorism, there must be an addition that focuses on the psychological aspect and a more narrow definition of noncombatant. This definition blends the statutory definition with the DoD version to accomplish Ganor's three elements while sufficiently framing critical words within the definition. The following serves as a blend of the two definitions: "Terrorism is the illegal use or threat of intentional, politically motivated violence against civilian targets by subnational groups or clandestine agents to instill fear in a population or coerce a government."

This definition, while not officially vetted, combines the strengths of both definitions and meets the required characteristics of a definition as outlined in the literature review. Although there is no consensus list of attributes required in a definition, the proposed definition addresses the top seven academic characteristics and all of the characteristics compiled from 88 governmental definitions as compiled by Schmid. ${ }^{119}$ In its separate components, it addresses the threat or use of violence, intentional conduct, political motivation, distinguishing civilian and military targets, identification of non-national actors, the psychological effect on a population, and coercive effect on a government. Each of these elements provides distinction in defining terrorism, distinguishing it from other methods of violence. Ganor argues that a clearer definition would place pressure on designated groups to target government forces using guerrilla tactics instead of targeting civilians, reducing civilian casualties in the process. ${ }^{120}$

\footnotetext{
${ }^{119}$ Schmid, 74-75.

${ }^{120}$ Ganor, The Counter-Terrorism Puzzle, 24.
} 


\section{Mentally Modeling a New Definition}

The model in Figure 1 provides clarity and objectivity to the proposed statutory definition to determine whether an attack is terrorism, thereby aiding in the designation of terrorist organizations. The model explains the elements of the proposed statutory definition and their relationship to each other, while distinguishing between guerrillas and terrorists. Reading Figure 1 from left to right, the model focuses on three different parties: the undesignated group, the civilian population (represented by the arc describing the audience, etc.), and the government. The model recognizes that both terrorists and guerrillas seek a political effect, but achieve their ends using different means in whom they target. The model also recognizes that legitimate interaction between the disaffected group and the government has failed, leading the group to resort to violence to achieve their political aims.

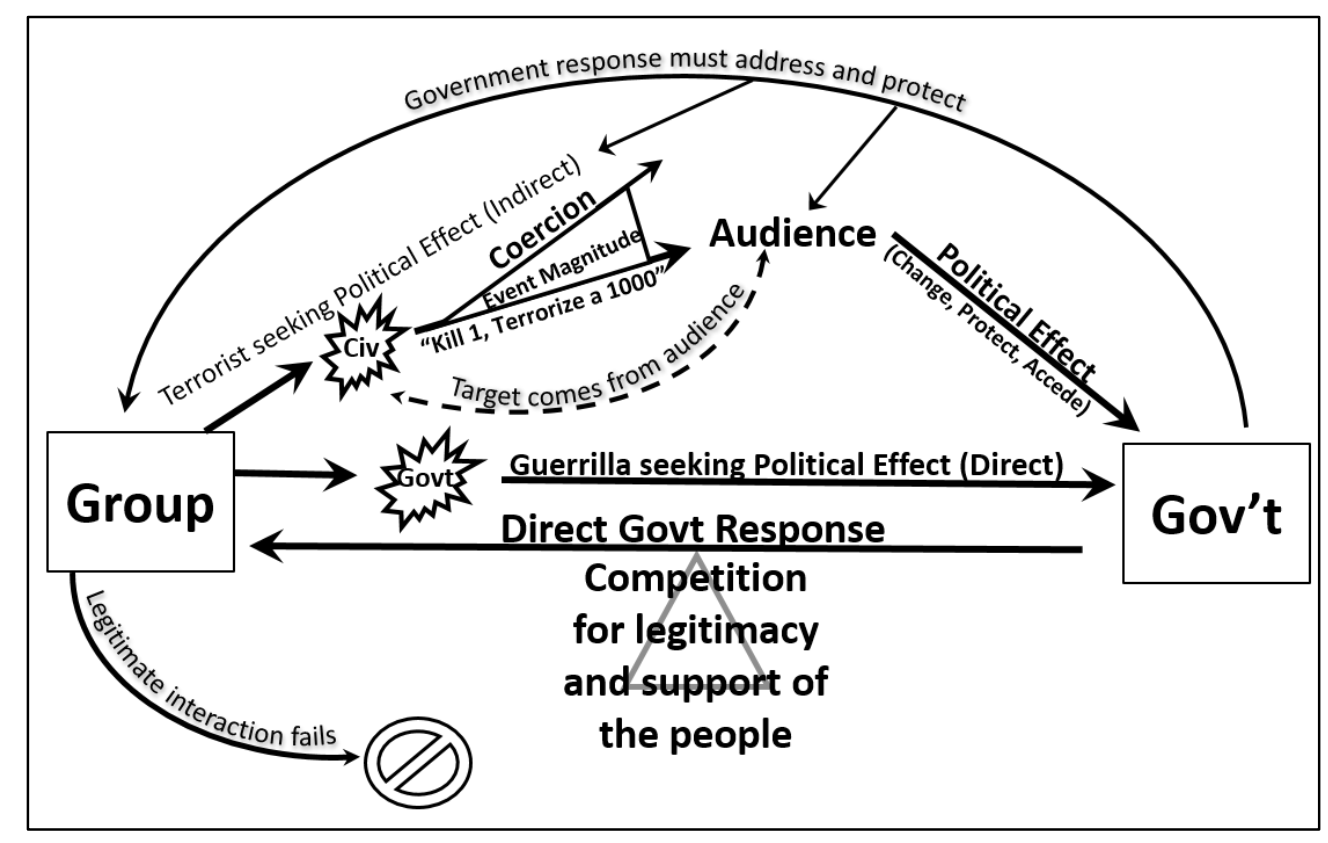

Figure 1. Model of Guerilla Tactics vs. Terrorism

Source: Author. 
In Figure 1, guerrillas directly target government forces because, as Ganor points out, they are specifically attempting to avoid civilian casualties by following moral norms in the conduct of combat. ${ }^{121}$ Paul Wilkinson utilizes Mao Tse-Tung's concept of gaining the mass support of the people to describe the goal of guerrilla warfare, and this idea provides the basis for revolutionary struggle. ${ }^{122}$ In the model, the competition between the two parties for legitimacy and support of the people signifies the goal. This direct action towards the government entity elicits a government response, and civilians are not the target, although they may become collateral damage during the violence. This action does not exclude guerrilla forces from using various methods against the government; it only limits acceptable targets to government forces.

Ganor argues that terrorists seek a political effect by targeting the "soft underbelly" of civilian targets, which reaps the impact of fear and media frenzy that surrounds such attacks. ${ }^{123}$ In the model, groups using terrorism indirectly seek political effect by attacking a civilian target, creating a coercive impact related to the magnitude and type of the event. Although not required, if the civilian target comes from the audience, the coercive influence increases by creating an "it could happen to me" effect. The affected audience is the driver for the terrorist's political effect on the government, although the terrorist cannot predict or control this outcome. Paul Wilkinson describes this effect, noting that despite the drastic increase in modern terrorism events, this method is remarkably unsuccessful in achieving strategic objectives. ${ }^{124}$ The government's response attempts to address the terrorists directly while protecting the audience. While shown linearly, the interaction between the three groups is circular and, in most cases, is a vicious downward cycle.

${ }^{121}$ Ganor, The Counter-Terrorism Puzzle, 18.

${ }^{122}$ Paul Wilkinson, Terrorism versus Democracy: The Liberal State Response, 2nd ed., Cass Series: Political Violence (London: Routledge, 2006), 14.

${ }^{123}$ Ganor, The Counter-Terrorism Puzzle, 18.

${ }^{124}$ Wilkinson, 16. 
The definitional alternative provides a more complete description and distinction of terrorism from other forms of violence. In addition to strengthening the composition of the definition, it specifically addresses the two glaring weaknesses addressed in academic discussions. Utilizing Figure 1 to aid in distinguishing terrorism from guerilla actions gives an objective tool for identifying terrorism, increasing the efficacy and effectiveness of the proposed definition. Increasing the objectivity of the definition also leads to more predictability and a moral "line in the sand" that encourages violence to be focused on government forces and not on civilians.

To summarize, the United States' definitional focus on the ambiguous nature of noncombatants and lack of identifying purpose, creates vagueness is the definition and enables mislabeling acts of violence as terrorism. Adapting the statutory terrorism definition to be independent of perspective distinguishes targets and identifies the purpose of terrorism, providing predictability in labeling the act. The definitional alternative provides these objective measures: strengthening the definition, and complementing the visual model for identifying terrorism. Chapter 2 will identify the effect that improving the definition of terrorism will have on reducing the "discretion in designation" of terrorist groups and mislabeling of groups based on a misunderstanding of their act, and provide a recommendation on consolidating definitions. 


\section{FUNCTIONAL ERRORS IN THE FRAMEWORK}

The United States constructs its framework for designating terrorist groups around allowing discretion in designation utilizing multiple layers of sanctions. The framework is a collection of E.O.s, U.S.C. statutes, and Public Law that authorizes the Secretary of State to designate groups as "terrorist" in coordination with the Treasury Secretary and the Attorney General. Since the framework utilizes vague and separate definitions of terrorism for each sanction, designating a terrorist organization can be a subjective, sometimes political, exercise. The Secretary of State's ability to exercise discretion in nominating a group for a particular list reflects this subjectivity. The use of the current framework to designate terrorism, while flexible, is flexible through subjectivity criteria and discretion in designation. This allows for the identification of guerrillas as "terrorists" where they might otherwise only be fighting the government.

Placing a group on the FTO list has a political effect and creates diplomatic leverage by signifying the attention that the United States is giving to the group, which legitimates the host countries' efforts. ${ }^{125}$ This creates the appearance of an U.S.-host nation alliance against the designated group, and can be a powerful tool to gain concessions in diplomatic negotiations. ${ }^{126}$ In some cases, however, designating groups to increase political maneuver space can create the appearance of inconsistent application, and make the United States seem hypocritical in its approach. ${ }^{127}$

While it is not appropriate to dispute sanctioning these irreconcilably violent groups, it is possible to question sanctioning groups that do not directly threaten the United States' citizens or national security as political leverage, which lowers the efficacy and legitimacy of the sanctions. Many of these groups will never disavow using terrorism tactics to advance their cause. These groups, such as Al-Qaida, Aum

\footnotetext{
${ }^{125}$ Pillar, 153; Cronin, "The 'FTO List,"” 8.

${ }^{126}$ Cronin, "The 'FTO List,"” 8-9.

${ }^{127}$ Ibid., 9.
} 
Shinrikyo, and Revolutionary Organization 17 November, directly target civilians to coerce governments or cause fear in the population. ${ }^{128}$ The United States has a responsibility to protect its citizens and national security by assisting partner nations in degrading terrorist group capabilities. Financial and immigration sanctions through terrorist group designation assist in disrupting these groups' operations. Sanctions affect not only those designated groups and individuals, but also the vast support network they depend upon. Pillar states that the point of sanctions is to prevent access to financial, material resources, and support for those who directly threaten the United States' national defense, foreign relations, or economic interests. In turn, sanctions target those who indirectly threaten the United States by supporting "terrorist" entities. ${ }^{129}$ Pillar and Cronin acknowledge that the SDN framework has been somewhat successful in blocking financial assets, and prosecuting or deporting individuals and groups for violations. ${ }^{130}$ The United States must take the lead in using effective sanctions to disrupt terrorist groups, using the framework in a consistent fashion to designate groups, and enhancing the legitimacy of the lists and their sanctions.

There are two problems with the framework's ability to distinguish between terrorist groups affecting the United States national security and guerrilla groups. The first issue with the framework is the subjective designation of "terrorist" groups, using separate definitions of terrorism and elements to identify groups. Utilizing separate, vague definitions and elements creates multiple standards of designation lists some groups inappropriately because of their tactics, not because of their purpose. The second problem is that subjectivity allows for excessive discretion in designation, both in sanctioning and not sanctioning groups. This discretion allows the use of designation as a political tool and not an objective process, which has complicating effects at the operational level, and reduces the legitimacy of

\footnotetext{
${ }^{128}$ Bureau of Counterterrorism, Country Reports 2012, 278-279, 250-251, 285-286.

${ }^{129}$ Paul R. Pillar, 151.

${ }^{130}$ Paul R. Pillar, 151; Cronin, “The 'FTO List,” 7.
} 
the designation. This chapter will address the effects of vague and separate definitions on the terrorist group designation process and the corresponding issues in United States' terrorist designation framework.

\section{$\underline{\text { Faults of Using Separate Definitions and Elements }}$}

The terrorism designation framework has three distinct designations - FTO, SDGT, and TEL applied to groups as discussed in the literature review. Authority to designate groups on the lists rests with the Secretary of State; the Treasury Secretary may also designate groups as SDGTs. ${ }^{131}$ The advantage to having different forms of designation allows bureaucratic flexibility to counter the speed at which groups and individuals can change aliases. This advantage diminishes when each designation utilizes separate definitions of "terrorism" or "terrorist activity" as a basis for designation, which sometimes inappropriately lists groups based on their tactics, not on their purpose. Related to this issue is the lack of academic research on the relationship between each designation, their related sanctions, and military and diplomatic operations. Designations as a FTO and SDGT are the focus of the discussion on this relationship because they prohibit the interaction of any U.S. person with designated groups to hamper military and diplomatic operations. Comparing the definition for designating FTOs to the definition used to designate SDGTs demonstrates the issues with using both lists to designate groups because it shows the potential for inconsistent application. Comparing the elements required to designate groups under each sanctions program reinforces the potential for inconsistent application because it suffers from the same issues.

There was no academic analysis found during the research for this monograph that compared FTO and SDGT definitions. All definition information is from U.S.C. or E.O.s, as appropriate, to authenticate the sources and provide direct comparisons. As a review and for direct visual comparison, the definition of terrorism to designate a FTO is "premeditated, political motivated violence perpetuated

\footnotetext{
${ }^{131}$ Cronin, "The 'FTO List,"” 2.
} 
against noncombatant targets by subnational groups or clandestine agents." ${ }^{\prime 132}$ This is in comparison to the definition of terrorism used to designate a SDGT:

(i) involves a violent act or an act dangerous to human life, property, or infrastructure; and (ii) appears to be intended-

(A) to intimidate or coerce a civilian population;

(B) to influence the policy of a government by intimidation or coercion; or

(C) to affect the conduct of a government by mass destruction, assassination, kidnapping, or hostage taking. ${ }^{133}$

The first issue is that the structure and composition of the two definitions are different. The FTO definition suffers from the faults identified in Section One, but at least provides a single, coherent sentence that describes terrorism, relying on that analysis here. The FTO definition is a single sentence that describes what "terrorism is", while the SDGT definition gives two required, separate elements, and the second element can fit any of three different circumstances. Both definitions identify violent actions as the focus of the definition, but the SDGT definition provides the widest possible categorization of violent acts - against human life, property, or infrastructure - as terrorism in its first element, and also gives specific violent acts in the second element. This violates academic characteristics of terrorism in two respects: it does not distinguish between combatants and noncombatants, and it categorizes property damage as a form of terrorism. The excessively broad view of who is a target of terrorism does not distinguish between combatants and noncombatants, possibly counting attacks against fielded military forces as terrorism. This counters analysis by Ganor, Gupta, Hoffman, Pillar, and Schmid, all who assert there must be distinction between combatants and noncombatants in a terrorism definition. ${ }^{134}$ Categorizing property damage as terrorism directly counters the analysis by Schmid, which states that labeling property damage as terrorism removes analytical vigor by recognizing sabotage and arson as

${ }^{132}$ Foreign Relations Authorization Act, Fiscal Years 1988 and 1989, Public Law 100-204, § 140, U.S. Statutes at Large 101 (1987): 1347-49, codified at U.S. Code 22 (2012), § 2656f(d)(2).

${ }^{133}$ Bush, 49080.

${ }^{134}$ Ganor, The Counter-Terrorism Puzzle, 17; Gupta, 9; Hoffman, 32; Pillar, 14; Schmid, 46-47. 
meeting the definition criteria. ${ }^{135}$ The first element of the SDGT definition is ineffective because it can result in an event causing the classification of a group as an SDGT that is not a threat to humans.

The second element of the SDGT definition identifies the apparent purpose of the terrorist act in three parts and is relatively coherent, covering the purpose of terrorism as coercion that is missing in the statutory definition. The second element is an "or" requirement, establishing that any of the three parts will suffice to fulfill the second element. The first two parts recognize the coercive nature against the population and against the government, a feature that Ganor, Gupta, Hoffman, and Pillar all require in their definitional analysis. ${ }^{136}$ The third part of the second element, which references the forms of violence, is unnecessary to the description of the conduct of terrorism by giving specific behaviors that can lead to a misunderstanding of a group's actions.

Three hypothetical examples illustrate the breadth and vagueness of the SDGT terrorism definition, which makes it unsuitable for use because it allows the classification of groups as SDGTs who are not a threat to the United States. The first example is an example of a political group in a foreign country that kidnaps a political rival during an election cycle to force concessions or actions by the ruling party in government, fulfilling both elements and qualifying as an SDGT according to definition. A second example is an activist group in a foreign country who conducts arson against infrastructure to protest the stance of their government on a particular social or political issue. This group qualifies as an SDGT because the group used violence against infrastructure to manipulate the government. The third example is a guerrilla group in a foreign country who attacks military or security force targets of their government in an attempt to rebel against perceived civil rights abuses, qualifying them as an SDGT since they utilized violence to coerce the government. None of the three scenarios fit the statutory definition of terrorism to designate the groups as FTOs, but all of them fit the SDGT definition. Utilizing a definition that allows these scenarios to be qualified as an SDGT violates the academic elements of terrorism, and is

\footnotetext{
${ }^{135}$ Schmid, 71, 84 .

${ }^{136}$ Ganor, "Defining Terrorism,” 288; Gupta, 10; Hoffman, 37; Pillar, 14.
} 
excessively broad in its approach. It also creates diplomatic issues when those theoretical groups come to power in their respective governments, but the sanctions prevent U.S. diplomats from interacting with the newly elected "SDGT" groups in accordance with 18 U.S.C. §2339B. The definition of terrorism for both designations should be the same to alleviate issues in using dissimilar designations because they lose meaning as a set of definitions when they include nearly all possible scenarios. Utilizing a definition that fulfills all of the academic elements would improve this issue while allowing for some flexibility in the interpretation of the actions.

The definition used by the SDGT framework, while marginally better in identifying the purpose of terrorism, provides no distinction between combatants and noncombatants instead providing an overwhelmingly broad inclusion of targets of terrorism. Utilizing this vague definition supports excessive discretion in designating groups as SDGTs when the designating authority is unable to fulfill the more stringent FTO definition. Using SDGT designation as a "workaround" creates an environment of discretion and hypocrisy in the justifications to list some groups as terrorist while not listing other groups. The next section addresses this discretion in designation in the FTO and SDGT framework that creates a perception of hypocrisy in designating groups, and how the designations are justified.

\section{Consequences of Excess Discretion in Designation}

The U.S. terrorist group framework has a great deal of flexibility and discretion in the designation process. Both the FTO and SDGT designations have established designation criteria that are outlined in 22 U.S.C. § $2656 \mathrm{f}$ and E.O. 13224, respectively. In 2011, Jongman related the list of FTOs as very small in relation to the number of existing violent groups worldwide, which according to the 2011 Routledge Handbook numbered well over 3,800 at the time. ${ }^{137}$ Cronin also identified that the number of groups on the FTO list represents a fraction of the overall number, but reflects the more durable international

\footnotetext{
${ }^{137}$ Albert J. Jongman, The Routledge Handbook of Terrorism Research, ed. Alex Peter Schmid, Routledge Handbooks (New York: Routledge, 2013), 344-48.
} 
terrorism groups that threaten the United States. ${ }^{138}$ While this data indicates that the U.S. does not wantonly designate groups, it does not address the ability for the Secretary of State to exercise discretion in listing or not listing groups. Applying the framework in an inconsistent manner jeopardizes the legitimacy of the sanctions and the credibility of the framework, leading to charges of hypocrisy in the application of the designations.

Donohue and Pillar separately discuss the criteria used to designate SDGTs and FTOs, respectively, and both of their discussions acknowledge the effect of excessive discretion in designation. Pillar only recognizes the three FTO designation criteria, and notes that, as of 2003, the financial and "support to terrorism" prosecutions have had a negligible effect with the deportation clause providing the greatest effect. ${ }^{139}$ Pillar identifies the greatest advantage of the FTO list is the stigma attached to a group placed on the list, signifying the official U.S. opposition to the group's activities, providing justification for other sanctions to take place. ${ }^{140}$ Pillar identifies political and diplomatic considerations as one of the drawbacks that affect the designation process because the Secretary of State is only "authorized" to designate rather than requiring designation. ${ }^{141}$ Pillar recognizes that the Secretary of State's discretion, while a negotiation tool, is also a liability by diminishing the value of the FTO list as exceptions are applied. ${ }^{142} \mathrm{He}$ uses the example of excluding the Irish Republican Army (IRA) as a designation as an FTO. While the IRA certainly threatened the United States interests, incorporating it into the peace process was more important than sanctioning the group. ${ }^{143}$ Pillar concludes his analysis of this weakness by charging that inconsistent application of the designation generates skepticism about the consistency of

\footnotetext{
${ }^{138}$ Audrey Kurth Cronin, How Terrorism Ends: Understanding the Decline and Demise of Terrorist Campaigns (Princeton, NJ: Princeton University Press, 2011), 75.

${ }^{139}$ Pillar, 151.

${ }^{140}$ Ibid., 152.

${ }^{141}$ Ibid., 153.

${ }^{142}$ Ibid.

${ }^{143}$ Ibid.
} 
the U.S. designation process. ${ }^{144}$ This discretion in designation can have a negative political and diplomatic effect if seen as hypocritical, while having a negative effect on military operations when the United States inaccurately designates a group through poor discretion.

Donohue is more incredulous at the power given to the Secretaries of State and the Treasury through E.O. 13224. Her primary issue with the SDGT criteria is the breadth of power it gives to the Secretaries of State and the Treasury's authority to designate any group who might be associated with terrorists, as well as anyone who associates with those on the list, as is the authority of the Secretary of the Treasury. ${ }^{145}$ Donohue says this exceptionally broad framework essentially removes any need to develop the intent of the group, instead relying only on their actions, which can unknowingly be connected to terrorism. ${ }^{146}$ This discretion in designation enabled by such wide criteria falls prey to the same faults as Pillar discussed in the FTO designation, namely that inconsistent designation practices reduce the legitimacy of the listing.

\section{Narrowing a Discretionary Designation Process}

There is no easy way to narrow the discretion in designating FTOs or SDGTs beyond implementing a strict review of the designation process, and having a more transparency in linking the group to terrorism. Enabling multiple in-depth interagency reviews of a group and their activities will assuage the feeling of hypocrisy through discretion in the designation. These in-depth reviews can only provide complete, accurate, and unbiased information about the group through a competent definition of terrorism and designation framework as discussed previously in this chapter. Transparency in the designation process also precludes charges of hypocrisy by directly linking how the group threatens the United States to their designation. This transparency must extend to all designations, with judicial review

\footnotetext{
${ }^{144}$ Pillar, 153.

${ }^{145}$ Donohue, 166.

${ }^{146}$ Ibid.
} 
and regular justification of continued sanctions required to keep a group on the list. Implementing these two processes will remove some of the discretion currently possessed by the DoS in designating groups. It will also reduce the second- and third-order effects that designation for political purposes has on interaction with designated groups at the operational diplomatic and military levels.

To summarize, the designation framework requires fixes to the two identified issues to make the process more effective. Using separate definitions and elements to identify groups as terrorist reduces the meaning of the designation by encompassing almost all scenarios, especially for the SDGT process. Combining the definitional breadth with the discretion in designation creates an inherently inconsistent labeling process, exacerbated by political and diplomatic influences. There is no clearly identified fix to these issues other than to improve the processes and definitions that the framework uses, increasing transparency, which increases the legitimacy of the designation. Increased transparency and rigor will reduce the opportunity for inconsistent designation practices to negatively impact diplomatic and military operations when interacting with listed terrorist groups. Two examples of this are in the case studies where the designation of the $\mathrm{MeK}$ and $\mathrm{CPN}(\mathrm{M})$ demonstrates the negative impacts of unclear definitions and designations on military and diplomatic operations. 


\section{CASE STUDIES}

\section{The Mujahedin-e Khalq and the United States}

This section presents the first of two case study tests, the Mujahedin-e Khalq, also known as the Peoples Mujahedin Organization of Iran (PMOI). ${ }^{147}$ The results support the theory of the United States' inconsistency in designating terrorist groups because of wide discretion in the framework leading to difficulty in military and diplomatic operations. This section provides a case study test of FTO designation of the MeK, and the impact on Coalition operations during Operation Iraqi Freedom (OIF) from 2003-2012, when the MeK was delisted as an FTO. The argument is that the designation of the MeK negatively affected Coalition operations because of the inconsistent application of the designation criteria and statutory definition. The designation of the MeK has proven a controversial topic on the application of FTO sanctions versus the impact on Coalition operations in a combat environment.

This argument develops in four steps. First is the motivation for selecting the MeK as a case study. Second is an outline of the main events surrounding the MeK's history, designation, and interaction with Coalition forces during OIF. Third is identifying the impacts of the FTO designation on the MeK and the United States' operations. Fourth is assessing the theory and conducting a brief summary.

The MeK are a unique case study on the effect of inconsistent FTO designation on military combat operations. According to the U.S. Department of State's "Foreign Terrorism Organization" website, the MeK is one of only nine groups designated as an FTO ever delisted. A further correlation between the "FTO" website and the SDGT list reveals that out of the four groups delisted as FTOs in the past decade, only the MeK does not remain listed on the SDGT list, and is one of only two groups ever

\footnotetext{
${ }^{147}$ This case study will refer to the Mujahedin-e Khalq simply as "MeK" throughout, although the group is known by several aliases, including "People's Mujahedin Organization of Iran" (PMOI) or "National Council of Resistance of Iran" (NCRI), which are the names that are recognized in the petitions heard by the U.S. District Court of Appeals for D.C.
} 
delisted as an SDGT. ${ }^{148}$ The MeK is also the only FTO directly involved in any U.S. large-scale combat operations out of all the delisted groups. ${ }^{149}$ The MeK first opposed the U.S. in the Iranian Revolution of the 1970s, but later allegedly offered to assist U.S. forces during OIF, the only group to do so on the list. The MeK are a highly controversial group, receiving tremendous political and legal support in their bid for delisting. The MeK case study provides several unique features that can be replicated in future operations.

Three students in Tehran founded the Mujahedin-e Khalq in 1965 to oppose Shah Mohammed Reza Pahlavi, who they viewed as a U.S. Government puppet, responsible for unwanted Western influence on the government. ${ }^{150}$ They embodied Marxist principles and Shi'a Islamic values in their violent struggle against the Iranian government, which began with their thwarted attempt at sabotaging a Tehran power station in $1971 .{ }^{151}$ Despite the general crackdown that followed their attempt, in which the Iranian government executed the founding members, the MeK continued violent opposition to the Shah throughout the 1970s. This violent opposition included attacks against Iranian infrastructure, and the assassination of three U.S. military officers and three U.S. contractors. ${ }^{152}$

Masud Rajavi took leadership of the MeK during the Iranian Revolution of 1977-1979 after the Shah released of thousands of political prisoners, including Rajavi. ${ }^{153}$ Rajavi aligned the MeK with Ayatollah Khomeini after the fall of the Shah in 1979, but Khomeini issued a fatwa forbidding Rajavi from running for president. This resulted in Rajavi turning the MeK against Khomeini's Islamic Republican Party (IRP) with violent attacks against government officials, including the 1981 bombing of

${ }^{148}$ U.S. Department of State, "Individuals and Entities Designated by the State Department under E.O. 13224,” http://www.state.gov/j/ct/rls/other/des/143210.htm (accessed 19 March 2014).

${ }^{149}$ Department of State, "Foreign Terrorist Organizations".

${ }^{150}$ Ervand Abrahamian, The Iranian Mojahedin (New Haven: Yale University Press, 1989), 88.

${ }^{151}$ Jeremiah Goulka et al., The Mujahedin-e Khalq in Iraq: a Policy Conundrum (Santa Monica, CA: Rand Publishing, 2009), 2.

${ }^{152}$ Ibid.

${ }^{153}$ Abrahamian, 171. 
the IRP headquarters that killed 70 IRP leaders. After the IRP suppressed the MeK with brutal tactics, Rajavi fled to Paris to form an Iranian dissident, umbrella group while his followers crossed the border into Iraq or formed underground cells. ${ }^{154}$

After Iraq's invasion of Iran in 1980 and the failed MeK uprising in 1981, Saddam Hussein began funding the MeK in exchange for intelligence, eventually leading to Saddam's invitation to the MeK leadership to join forces against Iran. Utilizing these resources, Rajavi formed the MeK into several wellarmed communes, and assisted Saddam in raiding across the Iranian border, resulting in a quarter of his 7,000 members as casualties. ${ }^{155}$ During this time, Rajavi implemented group indoctrination and psychological manipulation in order to sharpen the MeK's revolutionary ideology and maintain control as the MeK's leader. ${ }^{156}$ After Operation Desert Storm in 1991 in which the MeK saw little action, they continued to oppose the Iranian government throughout the 1990s while attempting to reform their image into a quasi-political party. ${ }^{157}$ This approach failed, however, and the MeK was among the groups initially listed by the DoS as a FTO on 8 October 1997, ostensibly for their connections and support of the Iraqi government. ${ }^{158}$ The MeK's political lobbying increased after their listing, focusing on members of the U.S. Congress to rescind the FTO designation, and recognize the MeK as a political activist group. ${ }^{159}$ Leading up to OIF, U.S. war planners viewed the MeK as an unofficial part of Saddam's military because of their armament, training, and cohesion. However, the planners did not give field commanders any guidance about how to treat the MeK, and after tactical-level negotiations, the MeK agreed to a

\footnotetext{
${ }^{154}$ Goulka et al., 2-3.

${ }^{155}$ Ibid., 3.

${ }^{156}$ Ronen Cohen, The Rise and Fall of the Mojahedin Khalq, 1987-1997: Their Survival After the Islamic Revolution and Resistance to the Islamic Republic of Iran (Brighton England: Sussex Academic Press, 2009 ), 36.

${ }^{157}$ Ibid., 162-163.

${ }^{158}$ Ibid., 171.

${ }^{159}$ Ibid., 172.
} 
cease-fire in April 2003 that allowed them to retain their weapons. ${ }^{160}$ A new agreement brokered in May 2003 disarmed the MeK, but did not force their surrender, instead consolidating the entire organization at their traditional headquarters at Camp Ashraf. ${ }^{161}$ During this time, staff lawyers for the U.S. forces debated the MeK's legal status since they were both a listed FTO non-state actor and a belligerent that operated with Iraqi forces, as well as Iranian exiles. ${ }^{162}$ In an attempt to determine their status, a review board convened, but did not determine each individual's legal status as required under the Third Geneva Convention; instead, it only determined each member's intelligence value and threat level to Coalition forces. ${ }^{163}$ Nearly all MeK members were determined to be "release-eligible" and allowed to stay in their assigned residence at Camp Ashraf. ${ }^{164}$

Meanwhile, on 9 December 2003, the Iraqi Governing Council (IGC) voted to expel the MeK within the next six months without identifying a destination. No other country would accept any members of a designated FTO, and the United Nations High Commissioner for Refugees (UNHCR) refused them refugee status because their legal status was not determined. ${ }^{165}$ As the June 2004 transfer date approached and no status had been determined, Secretary of Defense Rumsfeld designated the MeK as civilians protected by the Fourth Geneva Convention. This rash designation without tribunal review caused both legal and policy issues for the U.S. Government. ${ }^{166}$ This designation countered official U.S. policy that the Geneva Conventions did not apply to foreign terrorists in Iraq, and the only solution was detention. This made the MeK a FTO, protected party under the Geneva Conventions, meaning the U.S. had

\footnotetext{
${ }^{160}$ Goulka et al., 11.

${ }^{161}$ Ibid., 12.

${ }^{162}$ Ibid., 13.

${ }^{163}$ Ibid., 15-16.

${ }^{164}$ Ibid., 17.

${ }^{165}$ Ibid., 18.

${ }^{166}$ Ibid., 19.
} 
conflicting requirements to detain and prosecute them while also protecting them and providing assigned residence instead of detention. ${ }^{167}$

Because of their strong political support and lobby, the MeK were able to mount six challenges to their FTO designation, including the U.S. Court of Appeals D.C. Circuit decision, In Re: People's Mojahedin Organization of Iran (2012), ordering the DoS to review the designation of the MeK. ${ }^{168}$ The DoS denied each petition by the MeK through the D.C. Circuit Court of Appeals prior to the writ of mandamus, citing review of information sources that did not reveal any significant change in the MeK's designation criteria. ${ }^{169}$ During these challenges, in 1999, the D.C. Circuit Court of Appeals found that of the three FTO designation criteria, the third challenge - that the organization's activities threaten U.S. nationals or national security—was an unreviewable political question. ${ }^{170}$ The MeK petitioned the D.C. Circuit Court of Appeals for a writ of mandamus on 1 June 2012, which found that DoS exceeded the statutory 180-day review requirement on the 2010 petition. The Court ordered the DoS to conduct a review within the next four months from the date of writ. ${ }^{171}$ The writ stated that if the DoS did not take action within the prescribed four months, the Court would set aside the FTO designation. ${ }^{172}$ On 21 September 2012, the DoS issued a press release delisting the MeK as a FTO and SDGT, citing the MeK's "renunciation of violence, absence of confirmed acts of terrorism for more than a decade, and their cooperation in closing Camp Ashraf." 173

There are several consequences of the FTO designation of the MeK, most of them negatively affecting the United States military operations and its image. The impact of the designation on the MeK

\footnotetext{
${ }^{167}$ Goulka et al., 22.

${ }^{168}$ In Re: People's Mojahedin Organization of Iran, No. 12-1118, slip op., 2 (D.C. Cir. 1 June 2012).

${ }^{169}$ Ibid., 5-6.

${ }^{170}$ Ibid., 5.

${ }^{171}$ Ibid., 8-11.

${ }^{172}$ Ibid., 12.

${ }^{173}$ U.S. Department of State, "Delisting of the Mujahedin-E Khalq," http://www.state.gov/r/pa/prs/ps/ 2012/09/198443.htm (accessed 20 March 2014).
} 
before the beginning of OIF is not well researched, other than the ensuing legal challenges and political lobby to be delisted. The pace of legal challenges and political lobbying can be attributed to the derogatory effect that being "on the list" had on the MeK's ability to raise funds and legitimate its cause. Because Saddam Hussein supported the MeK during their initial FTO and SDGT designation, and lead-up to OIF, the impact was primarily on the flow of money from the United States. In the lead-up to OIF Goulka, et al., states in a RAND study on the MeK that Coalition planners did not adequately define a military mission regarding the MeK because of their confused status. ${ }^{174}$ Goulka, et al., states that throughout OIF, the U.S. did not treat the MeK as an FTO because of the desire to use them as a possible ally and intelligence-gathering resource, exposing the U.S. to criticism about its inconsistent approach. ${ }^{175}$ It is apparent from the series of PMOI v. Department of State petitions that the legal scrutiny placed on the designation criteria revealed that the system relies on discretion, especially in determining the group's threat to national security. While the sanctions hurt the MeK's ability to operate as an organization, it is clear there was an effect on the United States' operations as well.

Given the characteristics presented above, the outcome corresponds with the theory's prediction. The theory predicts that the United States is inconsistent in designating terrorist organizations because of discretion and a vague definition of terrorism. The failure to achieve accurate classification then has a negative effect on military operations. In the case of the $\mathrm{MeK}$, the inconsistent application of designation criteria is evident, resulting in negative effects on the United States' operations.

Goulka, et al., makes two recommendations to alleviate the negative issues that occurred because of the confused military operations with the MeK that apply to the theory. He first recommended that military planners should coordinate with the DoS and White House to identify specific objectives and clear rules of engagement regarding the treatment of belligerent groups that are politically sensitive. ${ }^{176}$

\footnotetext{
${ }^{174}$ Goulka et al., 35-36.

${ }^{175}$ Ibid., 41.

${ }^{176}$ Ibid., 50.
} 
His next recommendation is that the Departments of State and Defense must coordinate to manage communications about the designation of groups both on the battlefield and in the designation framework. ${ }^{177}$ The PMOI v. Department of State petitions imply a recommendation that the United States must review and clarify the designation criteria to allow for legal review and consistency in designating groups. The evidence from the case study supports the hypothesis and suggests that the United States must review its designation procedures and criteria.

The MeK are a unique case study in their multiple levels of involvement with U.S. military and diplomatic operations. While they were obviously a violent group that opposed the U.S. during the Iranian Revolution of the 1970s, basing their terrorist designation off these incidents obviously degraded the United States' operations. The degradation occurred because the U.S. utilized discretion to maintain the MeK on the list without acknowledging their change in purpose or threat level to the U.S. The evidence indicates that these circumstances could reoccur if there are not improvements to the designation criteria.

\footnotetext{
${ }^{177}$ Goulka et al., 52.
} 


\section{The Communist Party of Nepal (Maoist) and the United States}

This section presents the second of two case study tests, the Communist Party of Nepal (Maoist). The results tend to prove the theory of the United States' inconsistency in designating terrorist groups because of wide discretion in utilizing multiple designations within the framework that complicates diplomatic relations. This section provides a case study test of SDGT designation of the CPN(M) and the impact on diplomatic interactions during the $\mathrm{CPN}(\mathrm{M})$ rise to power. The argument is that the politically motivated designation of the CPN(M) was enabled by broad SDGT terrorism definition and evaluation criteria. The inconsistent application of SDGT sanctions is not explained without considering the vague definition and broad discretion in designation application.

This argument develops in four steps. First is the motivation for selecting the CPN(M) as a case study. Second is an outline of the main events surrounding the CPN(M)'s history, designation and after their rise to power, their interaction with U.S. diplomats. Third is identifying the impacts of the SDGT designation on the CPN(M) and the United States. Fourth is to assess the theory and conduct a brief summary.

The CPN(M) is a unique case study on the effect of discretionary use of multiple terrorist organization designations to achieve FTO-like sanctions. According to the Department of State's “Terrorist Exclusion List" website, the CPN(M) is the only group ever delisted from the TEL. ${ }^{178}$ The DoS also lists the $\mathrm{CPN}(\mathrm{M})$ as one of only two groups ever delisted from the SDGT, the other group being the MeK. ${ }^{179}$ Further, the CPN(M) is one of only three U.S.-sanctioned terrorist groups to win a democratic election besides Hezbollah and Hamas. ${ }^{180}$ The $\mathrm{CPN}(\mathrm{M})$ case study provides a perspective on designating a group as a SDGT utilizing very broad designating criteria and definition and the impact of discretionary

\footnotetext{
${ }^{178}$ U.S. Department of State, “Terrorist Exclusion List,” http://www.state.gov/j/ct/rls/other/des/123086.htm. (accessed December 14, 2013).

${ }^{179}$ U.S. Department of State, "Individuals and Entities Designated Under E.O. 13224."

${ }^{180}$ Joshua Gross, "Proscription Problems: The Practical Implications of Terrorist Lists On Diplomacy and Peacebuilding in Nepal”, Praxis: The Fletcher Journal of Human Security 26 (2011): 40.
} 
designation on diplomatic relations.

The Communist Party of Nepal (Maoist) came to being out of the combination and splitting of several Leftist movements that opposed the corrupt, centrist government of Nepal between 1949 and 1990. ${ }^{181}$ It arrived in its current form in May 1994, when the Communist Party of Nepal (Unity Centre) (CPN(UC)) split into two factions because of animosity between party leaders, but communicated under the guise of ideological differences. ${ }^{182}$ The CPN(M) took form in March 1995 under the leadership of Prachanda, a former general secretary of the CPN(UC), who developed a campaign to conduct a "people's war" to usher in a new form of government after being locked out of mid-term elections in 1994. ${ }^{183}$ After organizing the party and developing support, in February 1996 the CPN(M) then submitted a list of 40 demands to the Prime Minister, which if not met by February 17, 1996, would result in the start of an armed struggle. When the Prime Minister ignored the CPN(M) they struck an Agricultural Bank and burned its loan papers, beginning the "people's war". 184

During the first five years of the "people's war", attacks by the CPN(M) were largely confined to raids on remote police posts, gradually moving from small incidents to large scale attacks on police stations, creating a power vacuum that fostered local support for the CPN(M) as they opposed the monarchy. ${ }^{185}$ The increasing size and intensity of the attacks led the government to activate a portion of the Royal Nepalese Army (RNA) in March 2000 to support the police in countering the CPN(M). ${ }^{186}$ After Prince Dipendra killed the king and queen along with eight other Royal Family members in the Royal Family Massacre in June 2001, the unpopular brother to the late king, King Gyanendra, was crowned and

${ }^{181}$ Deepak Thapa and Bandita Sijapati, A Kingdom under Siege: Nepal's Maoist Insurgency, 1996 to 2003, updated ed. (Kathmandu: The Printhouse, 2004), 43-44.

${ }^{182}$ Ibid., 43.

${ }^{183}$ Ibid., 45.

${ }^{184}$ Ibid., 48.

${ }^{185}$ Ibid., 106.

${ }^{186}$ Michael Hutt, Himalayan People's War: Nepal's Maoist Rebellion (Bloomington: Indiana University Press, 2004), 71. 
increased the offensive against the $\mathrm{CPN}(\mathrm{M}) .{ }^{187} \mathrm{In}$ an attempt to control the rising $\mathrm{CPN}(\mathrm{M})$ insurgency, Gyanendra declared a state of emergency in November 2001 to fully activate the RNA, leading to fourteen months of indecisive violence. ${ }^{188}$ After political upheaval in 2002 led to the dissolution of the parliament and canceling of provisional elections, Gyanendra seized full executive power and installed a new prime minister and cabinet. Each of the three successive attempts to reform the cabinet between 2002 and 2005 failed, resulting in Gyanendra seizing direct power as a monarch in 2006 and creating a triangular struggle for power between the king, the political parties and the CPN(M). ${ }^{189}$

During the almost ten-year conflict in which an estimated 13,000 Nepalese were killed, both the Government of Nepal and the CPN(M) were cited for their rampant human rights abuses and tactics. ${ }^{190}$ During the conflict, the United States did not mention the CPN(M) in the Patterns of Global Terrorism report until the 2001 report, which briefly mentioned them as revolutionary group using terrorist tactics, although those tactics are not defined. ${ }^{191}$ The CPN(M) actively threatened the U.S., India and China for interference in the "internal affairs" of Nepal. ${ }^{192}$ After the CPN(M) claimed responsibility for the 2002 murder of two off-duty local U.S. Embassy guards and bombing two Coca-Cola plants in which no one was injured. The State Department then listed the CPN(M) as a SDGT on October 31, 2003, for supporting terrorist activity and placed them on the TEL to prevent movement to the United States. ${ }^{193}$ At the time, the SDGT and TEL designation was seen by Indian newspapers as a political ploy by the United

\footnotetext{
${ }^{187}$ Paul K. Davis et al., Understanding and Influencing Public Support for Insurgency and Terrorism (Santa Monica, CA: RAND Corporation, 2012), 122n6.

${ }^{188}$ John Whelpton, A History of Nepal (Cambridge: Cambridge University Press, 2005), 218.

${ }^{189}$ Davis et al., 123.

${ }^{190}$ Gross, 40.

${ }^{191}$ U.S. State Department, Office of the Coordinator for Counterterrorism, Patterns of Global Terrorism 2001 (Washington, DC, 2002), 11.

${ }^{192}$ Bruce Vaughn, "Nepal: Background and U.S. Relations.” No. RL31599. (Congressional Research Service Report for Congress, 2006), 14.

${ }^{193}$ U.S. State Department, Office of the Coordinator for Counterterrorism, Country Reports on Terrorism 2003 (Washington, DC, 2004), 143.
} 
States to gain Nepal's support for the Global War on Terror in exchange for a coercive approach against the $\mathrm{CPN}(\mathrm{M}) .{ }^{194}$ During their listing, the $\mathrm{CPN}(\mathrm{M})$ continued violence and in 2006, the people held widespread protests against the monarchy's authoritarianism and after a 17-day standoff, Gyanendra endorsed peace negotiations between the political parties and the $\mathrm{CPN}(\mathrm{M})$. This agreement led to the 2006 Comprehensive Peace Accord (CPA), which allowed the CPN(M) to run for election in 2008, where they won the largest block of parliamentary seats. ${ }^{195}$

Because of the CPN(M)'s simultaneous SDGT listing and the electoral results, the U.S Embassy was forbidden from directly consulting or interacting with leadership within the new parliament under the prohibitions of E.O. 13224, which did not exclude diplomats. ${ }^{196}$ After some delay, an OFAC license was secured that enabled continued dialogue between the United States and the CPN(M) regarding the peace process and eventual delisting, which did not occur until 2012. ${ }^{197}$ The delisting occurred after the State Department determined that the CPN(M) no longer conducted terrorist activity that posed a threat to U.S. citizens or national security. ${ }^{198}$

There are several impacts of the United States' designation of the CPN(M) as a SDGT and TEL, most of which negatively affect the United States diplomatic efforts. In an interview with Joshua Gross, the legal advisor for the $\mathrm{CPN}(\mathrm{M})$ noted at the only tangible effect of the United States designating the CPN(M) as a SDGT and placing them on the TEL was difficulty in obtaining visas when members traveled outside of Nepal. ${ }^{199}$ The SDGT designation had a considerable effect on U.S. diplomatic engagement in the CPA. In his critique of the U.S. policy regarding the CPN(M), Gross states that the terrorist tag isolated the United States from the peace process and allowed the vacuum to be filled by

\footnotetext{
${ }^{194}$ Hutt, 197.

${ }^{195}$ Gross, 40.

${ }^{196}$ Ibid., 44-45.

${ }^{197}$ Ibid., 45.

${ }^{198}$ Bureau of Counterterrorism, Country Reports 2012, 165.

${ }^{199}$ Gross, 46.
} 
India and the United Nations. ${ }^{200}$ Gross interviewed several U.S. and UN diplomats who noted that terrorist lists are "blunt instruments" that prevented U.S. involvement in the early peace process, possibly prolonging violence. ${ }^{201}$ This prevented U.S. engagement with the CPN(M) and may have created suspicion of the United States' intentions during diplomatic interactions after the OFAC license was issued. In Gross' interview with Dr. Duman Thapa of the Asian Studies Center for Peace and Conflict Transformation, Thapa noted that there was a lack of U.S. transparency frustrated the CPN(M)'s compliance with peace benchmarks. The U.S. policy was not flexible when the CPN(M) took steps to participate in the political process, lacking a reward for eschewing violence. ${ }^{202}$ The impact of designation was negligible on the $\mathrm{CPN}(\mathrm{M})$, but may have prolonged violence and damaged the image of the United States through lack of transparency in designation criteria and flexibility to assist the peace process.

Given the characteristics of the CPN(M) case study, the outcome corresponds with the theory's prediction. The theory predicts that the United States is inconsistent in designating terrorist organizations because of wide discretion in designation using a vague definition of terrorism. The discretion to apply a terrorism designation based on three attacks that did not directly affect the United States had a subsequently negative effect on diplomatic efforts in the peace process.

Gross makes three recommendations to create a more flexible, precise and transparent designation process that is responsive to diplomatic situations. He first recommends a clear path to legitimacy, which may compel armed groups to change paths by informing groups of the process for designations removal. ${ }^{203}$ His second recommendation is a type of probationary status that would incentivize behavior change and inclusion in a peace process that reduces violence. ${ }^{204}$ The third recommendation is to exempt peacebuilding efforts from prohibition by reforming the designation

\footnotetext{
${ }^{200}$ Gross, 46.

${ }^{201}$ Ibid., 47 .

${ }^{202}$ Ibid.

${ }^{203}$ Ibid., 53.

${ }^{204}$ Ibid.
} 
process. ${ }^{205}$ Gross explains that OFAC should determine if peacebuilding efforts have a "tangible" value that prohibited under E.O. 13224, which would clarify the existing framework. The evidence from this case study supports the hypothesis that the United States must review its designation process and criteria for clarity and effectiveness.

The CPN(M) are a unique case study in the lack of impact that designation had on their organization combined with the significant impact on U.S. diplomatic interaction with their newly elected members. While they were obviously a violent group, they only directly opposed the United States' involvement in internal Nepalese affairs. Designating them as a terrorist organization affected the United States' ability to be part of the peace process by forbidding diplomatic involvement, instead forcing the use of coercive processes to have a marginal effect on the group. The evidence indicates that this circumstance could reoccur if there are not improvements in the designation criteria that clarify the process for listing and delisting and create an allowance for diplomatic involvement.

The case studies reveal the negative effects of excessive discretion in designation and a vague definition of terrorism on military and diplomatic affairs. Military operations are negatively affected by a lack of clarity in terrorism definition and designation criteria, which complicates rules of engagement and detention status based on their status(es). Political influence on terrorist designation complicates diplomatic efforts by frustrating involvement in peace processes that alleviate conflict and its associated loss of life. Both case studies support the hypothesis that the United States is inconsistent in designating terrorist organizations because of a wide discretion in applying designation labels using a vague definition of terrorism. The designation criteria focus on behaviors and not the purpose of the groups, enabled by a vague terrorism definition that does not discern between terrorism and other forms of political violence. The case studies support the need for review of the designation criteria to eliminate inconsistency in their application. The case studies also support the need for a consolidated definition of terrorism across all

\footnotetext{
${ }^{205}$ Gross, 54.
} 
designations to address the purpose of terrorism and adequately distinguish it from other forms of violence. Utilizing the lessons from these case studies will help to reduce future negative impacts of the terrorism designation framework on military and diplomatic operations. 


\section{PATH TO A DEFINITION}

The debate on the definition of terrorism does not have a foreseeable end. As Walter Laqueur notes, seeking a definition beyond identification of violent tactics used to achieve a political end is "bound to lead to endless controversies." ${ }^{206}$ Governments, however, do not have the option to debate the definitions of terrorism or have ineffective frameworks without facing the consequences of their shortcomings. The U.S. Government must have an effective, efficacious designation framework to distinguish between terrorists and guerrillas. The designation framework must be have complementary criteria and a sound, common definition of terrorism that reduces discretion and inconsistent application of terrorist designations. Complementary criteria provide a common understanding of the characteristics of a terrorist group. The two case studies demonstrate the consequences of an ineffective definition and imprecise designation. Rather than reducing options, a clear definition and effective framework increases options and makes designation more efficacious by creating a better understanding of the opposing actor. Reviewing the main points of the research should lead to conclusions about a way forward in effectively designating terrorist organizations.

The academic discussion provides some common elements to develop a sound definition of terrorism. A sound, common definition recognizes the violent nature of terrorism, defines noncombatants, and identifies the political and psychological purpose of the terrorist act, enabling a clear distinction between terrorist and other types of groups. A definition of noncombatants must protect civilians without encompassing all possible targets in an effort to aid in distinguishing the purpose of terrorism.

Understanding the political and psychological purpose of a terrorist act distinguish it from common crime or guerrilla warfare, increasing the understanding of the violent act. These elements should provide the structure for improving the current statutory definition of terrorism.

\footnotetext{
${ }^{206}$ Walter Laqueur, Terrorism (London: Weidenfeld and Nicolson, 1977), 79.
} 
The current statutory definition used to designate terrorist organizations suffers from two deficiencies in the elements of a sound definition. It does not provide adequate distinction of noncombatants or recognize the political or psychological purpose of terrorism. There is no statutory definition of noncombatants; an unofficial reference by the State Department gives an overbroad definition that encompasses everyone but fielded military forces. Not incorporating the political and psychological purpose of terrorism in the definition allows context to be imprecise and encompass nearly any act. An alternative definition that builds on the strengths of the DoS and DoD definitions and is visually modeled, clarifies the definition of terrorism to enable a more effective designation framework.

As reflected in the structure of the designation framework, the U.S. Government has created a system of designation that relies on vagueness and discretion to provide options. This system has multiple, uncoordinated features that places a substantially greater burden of proof on designating FTOs while providing little oversight of SDGT designation. The imbalance continues with the ability for FTOs to challenge their designation while SDGTs have no such recourse. The vagueness of the terrorism designation system allows political influences to wreak havoc on the consistency in both listing and delisting terrorist organizations. This inconsistency opens the system up to charges of hypocrisy and imbalance, further exacerbating the issue. The U.S. Government's imbalance in designation creates unpredictable second- and third-order effects that negatively affect military and diplomatic operations.

The case studies of the Mujahedin-e Khalq and Communist Party of Nepal (Maoist) illustrate the effect that lack of clarity and excessive discretion has on military and diplomatic efforts. They also demonstrate the complex nature of designating terrorist organizations, and the need for clear criteria and definitions to distinguish between types of groups. Most importantly, they validate the need for a comprehensive review of the terrorist organization designation system to avoid such difficult circumstances arising in the future.

There are several conclusions to make from the research in this monograph. The first is that defining terrorism and designating terrorist organizations are difficult and contentious undertakings that 
governments must accomplish in order to effectively sanction terrorist organizations. Next, the United States must revise both the definition and the framework to ensure compatibility and complementary effects. The revision is required because the government, while attempting to preserve options, has developed a terrorism definition that is ineffective in distinguishing terrorism from other violent acts. This contributes to the DoS having wide discretion in designating terrorist organizations within the designation framework, which is compounded by multiple, incompatible definitions and wide latitude in designation criteria. The negative results of using an imprecise definition and expansive designation criteria is demonstrated in the two case studies, which are apt to be repeated if no definitional, procedural, or structural changes are made to the terrorist designation process.

The purpose of this monograph is not to invalidate or otherwise disparage the terrorist organization designation system. It does argue that the system is inefficient through its lack of clear, coordinated criteria and definitions, which creates difficult circumstances that need not exist. Currently, the power to restructure and coordinate the designation framework lies in both the Congressional and Presidential realms. The U.S. military does not have the power to restructure the designation framework or directly affect the designation of groups, but must understand the implications of group designations and account for them in planning operations.

This monograph also does not argue for a designation label to fit the circumstances of every violent group, nor a "one size fits" all approach. It does argue that for the designation framework to be efficacious and effective, it must provide scalable designation options that have compatible definitions and criteria. The U.S. must realize that there is no ultimate way to define of terrorism or set evaluation criteria, but there are many ways to create wrong ones. There must be an understanding that to meet the requirement for a complementary set of definitions and criteria across a range of designation options, leaders must make decisions about the composition of the current system in the face of an ever-expanding field of study. The U.S. cannot afford to suffer "paralysis by analysis" any more than it can afford to have a system that produces undesired consequences. 
APPENDIX A: LIST OF FTOs and SDGTs

Table 1. List of FTOs, SDGTs, and SDTs

\begin{tabular}{|c|c|c|c|}
\hline \multicolumn{4}{|c|}{ Specially Designated Nationals and Blocked Persons List Search } \\
\hline \multicolumn{4}{|c|}{ List of FTOs, SDGTs and SDTs } \\
\hline \multicolumn{4}{|c|}{ As Of 17 March 2014} \\
\hline & \multicolumn{3}{|c|}{ Organizations listed as FTOs } \\
\hline \# & Name & Type & $\operatorname{Program}(\mathbf{s})$ \\
\hline 1 & KATA’IB HIZBALLAH & Entity & FTO, IRAQ3, SDGT \\
\hline 2 & ABDALLAH AZZAM BRIGADES & Entity & FTO, SDGT \\
\hline 3 & ABU NIDAL ORGANIZATION & Entity & FTO, SDGT, SDT \\
\hline 4 & ABU SAYYAF GROUP & Entity & FTO, SDGT \\
\hline 5 & AL-AQSA MARTYRS BRIGADE & Entity & FTO, SDGT, SDT \\
\hline 6 & AL-JIHAD & Entity & FTO, SDGT, SDT \\
\hline 7 & AL-MULATHAMUN BATTALION & Entity & FTO, SDGT \\
\hline 8 & AL-QA'IDA IN THE ARABIAN PENINSULA & Entity & FTO, SDGT \\
\hline 9 & AL-SHABAAB & Entity & FTO, SDGT, SOMALIA \\
\hline 10 & ANSAR AL-DINE & Entity & FTO, SDGT \\
\hline 11 & ANSAR AL-ISLAM & Entity & FTO, SDGT \\
\hline 12 & ANSAR AL-SHARI'A IN BENGHAZI & Entity & FTO, SDGT \\
\hline 13 & ANSAR AL-SHARI'A IN DARNAH & Entity & FTO, SDGT \\
\hline 14 & ANSAR AL-SHARI'A IN TUNISIA & Entity & FTO, SDGT \\
\hline 15 & ANSARU & Entity & FTO, SDGT \\
\hline 16 & ARMY OF ISLAM & Entity & FTO, SDGT \\
\hline 17 & ASBAT AL-ANSAR & Entity & FTO, SDGT \\
\hline 18 & AUM SHINRIKYO & Entity & FTO, SDGT \\
\hline 19 & BOKO HARAM & Entity & FTO, SDGT \\
\hline 20 & CONTINUITY IRA & Entity & FTO, SDGT \\
\hline 21 & EUZKADI TA ASKATASUNA & Entity & FTO, SDGT \\
\hline 22 & GAMA'A AL-ISLAMIYYA & Entity & FTO, SDGT, SDT \\
\hline 23 & HAMAS & Entity & FTO, SDGT, SDT \\
\hline 24 & HAQQANI NETWORK & Entity & FTO, SDGT \\
\hline 25 & HARAKAT UL-JIHAD-I-ISLAMI/BANGLADESH & Entity & FTO, SDGT \\
\hline 26 & HARAKAT UL-MUJAHIDEEN & Entity & FTO, SDGT \\
\hline 27 & HIZBALLAH & Entity & FTO, SDGT, SDT, SYRIA \\
\hline 28 & INDIAN MUJAHIDEEN & Entity & FTO, SDGT \\
\hline 29 & ISLAMIC ARMY & Entity & FTO, SDGT, SDT \\
\hline 30 & ISLAMIC JIHAD GROUP & Entity & FTO, SDGT \\
\hline 31 & ISLAMIC MOVEMENT OF UZBEKISTAN & Entity & FTO, SDGT \\
\hline
\end{tabular}




\begin{tabular}{|c|c|c|c|}
\hline \# & Name & Type & Program(s) \\
\hline 32 & JAISH-I-MOHAMMED & Entity & FTO, SDGT \\
\hline 33 & JAM'AT AL TAWHID WA'AL-JIHAD & Entity & FTO, SDGT \\
\hline 34 & JEMAA ISLAMIYAH & Entity & FTO, SDGT \\
\hline 35 & JEMMAH ANSHORUT TAUHID & Entity & FTO, SDGT \\
\hline 36 & JUNDALLAH & Entity & FTO, SDGT \\
\hline 37 & KAHANE CHAI & Entity & FTO, SDGT, SDT \\
\hline 38 & KURDISTAN WORKERS' PARTY & Entity & FTO, SDGT, SDNTK \\
\hline 39 & LASHKAR E-TAYYIBA & Entity & FTO, SDGT \\
\hline 40 & LASHKAR I JHANGVI & Entity & FTO, SDGT \\
\hline 41 & LIBERATION TIGERS OF TAMIL EELAM & Entity & FTO, SDGT \\
\hline 42 & LIBYAN ISLAMIC FIGHTING GROUP & Entity & FTO, SDGT \\
\hline 43 & NATIONAL LIBERATION ARMY & Entity & FTO, SDGT \\
\hline 44 & $\begin{array}{l}\text { NEW PEOPLE'S ARMY / COMMUNIST PARTY OF THE } \\
\text { PHILIPPINES }\end{array}$ & Entity & FTO, SDGT \\
\hline 45 & PALESTINE ISLAMIC JIHAD - SHAQAQI FACTION & Entity & FTO, SDGT, SDT \\
\hline 46 & $\begin{array}{l}\text { PALESTINE LIBERATION FRONT - ABU ABBAS } \\
\text { FACTION }\end{array}$ & Entity & FTO, SDGT, SDT \\
\hline 47 & $\begin{array}{l}\text { POPULAR FRONT FOR THE LIBERATION OF } \\
\text { PALESTINE }\end{array}$ & Entity & FTO, SDGT, SDT \\
\hline 48 & $\begin{array}{l}\text { POPULAR FRONT FOR THE LIBERATION OF } \\
\text { PALESTINE - GENERAL COMMAND }\end{array}$ & Entity & FTO, SDGT, SDT \\
\hline 49 & REAL IRA & Entity & FTO, SDGT \\
\hline 50 & REVOLUTIONARY ARMED FORCES OF COLOMBIA & Entity & FTO, SDGT, SDNTK \\
\hline 51 & REVOLUTIONARY ORGANIZATION 17 NOVEMBER & Entity & FTO, SDGT \\
\hline 52 & $\begin{array}{l}\text { REVOLUTIONARY PEOPLE'S LIBERATION } \\
\text { PARTY/FRONT }\end{array}$ & Entity & FTO, SDGT \\
\hline 53 & REVOLUTIONARY STRUGGLE & Entity & FTO, SDGT \\
\hline 54 & SALAFIST GROUP FOR CALL AND COMBAT & Entity & FTO, SDGT \\
\hline 55 & SHINING PATH & Entity & FTO, SDGT \\
\hline 56 & TEHRIK-E TALIBAN PAKISTAN (TTP) & Entity & FTO, SDGT \\
\hline 57 & UNITED SELF-DEFENSE FORCES OF COLOMBIA & Entity & FTO, SDGT, SDNTK \\
\hline
\end{tabular}




\begin{tabular}{|c|c|c|c|}
\hline & \multicolumn{3}{|c|}{ Organizations not listed as FTOs but listed as SDTs or SDGTs } \\
\hline \# & Name & Type & Program(s) \\
\hline 1 & $\begin{array}{l}\text { IRANIAN MINISTRY OF INTELLIGENCE AND } \\
\text { SECURITY }\end{array}$ & Entity & $\begin{array}{l}\text { HRIT-IR, IFSR, IRAN-HR, } \\
\text { SDGT, SYRIA }\end{array}$ \\
\hline 2 & AFGHAN SUPPORT COMMITTEE & Entity & SDGT \\
\hline 3 & AFRI BELG COMMERCIO E INDUSTRIA LDA & Entity & SDGT \\
\hline 4 & AL BARAKA EXCHANGE LLC & Entity & SDGT \\
\hline 5 & AL FURQAN & Entity & SDGT \\
\hline 6 & AL MANAR TV & Entity & SDGT \\
\hline 7 & AL NOUR RADIO & Entity & SDGT \\
\hline 8 & AL RASHID TRUST & Entity & SDGT \\
\hline 9 & AL REHMAT TRUST & Entity & SDGT \\
\hline 10 & AL-AKHTAR TRUST INTERNATIONAL & Entity & SDGT \\
\hline 11 & AL-AQSA & Entity & SDGT \\
\hline 12 & AL-AQSA E.V. & Entity & SDGT \\
\hline 13 & AL-AQSA FOUNDATION & Entity & SDGT \\
\hline 14 & AL-AQSA FOUNDATION & Entity & SDGT \\
\hline 15 & AL-AQSA FOUNDATION & Entity & SDGT \\
\hline 16 & AL-AQSA FOUNDATION & Entity & SDGT \\
\hline 17 & AL-AQSA ISLAMIC BANK & Entity & SDGT, SDT \\
\hline 18 & AL-AQSA TV & Entity & SDGT \\
\hline 19 & AL-BAKOUN ALA AL-AHD ORGANIZATION & Entity & SDGT \\
\hline 20 & AL-BARAKAAT & Entity & SDGT \\
\hline 21 & AL-BARAKAAT BANK & Entity & SDGT \\
\hline 22 & AL-BARAKAAT BANK OF SOMALIA & Entity & SDGT \\
\hline 23 & $\begin{array}{l}\text { AL-BARAKAAT GROUP OF COMPANIES SOMALIA } \\
\text { LIMITED }\end{array}$ & Entity & SDGT \\
\hline 24 & AL-BARAKAT FINANCE GROUP & Entity & SDGT \\
\hline 25 & AL-BARAKAT FINANCIAL HOLDING COMPANY & Entity & SDGT \\
\hline 26 & AL-BARAKAT GLOBAL TELECOMMUNICATIONS & Entity & SDGT \\
\hline 27 & AL-BARAKAT INTERNATIONAL & Entity & SDGT \\
\hline 28 & AL-BARAKAT INVESTMENTS & Entity & SDGT \\
\hline 29 & AL-HAMATI SWEETS BAKERIES & Entity & SDGT \\
\hline 30 & $\begin{array}{l}\text { AL-HARAMAIN \& AL MASJED AL-AQSA CHARITY } \\
\text { FOUNDATION : BOSNIA BRANCH }\end{array}$ & Entity & SDGT \\
\hline 31 & AL-HARAMAIN : AFGHANISTAN BRANCH & Entity & SDGT \\
\hline 32 & AL-HARAMAIN : ALBANIA BRANCH & Entity & SDGT \\
\hline 33 & AL-HARAMAIN : BANGLADESH BRANCH & Entity & SDGT \\
\hline 34 & AL-HARAMAIN : ETHIOPIA BRANCH & Entity & SDGT \\
\hline 35 & AL-HARAMAIN : INDONESIA BRANCH & Entity & SDGT \\
\hline 36 & AL-HARAMAIN : KENYA BRANCH & Entity & SDGT \\
\hline 37 & AL-HARAMAIN : PAKISTAN BRANCH & Entity & SDGT \\
\hline
\end{tabular}




\begin{tabular}{|c|c|c|c|}
\hline \# & Name & Type & Program(s) \\
\hline 38 & AL-HARAMAIN : TANZANIA BRANCH & Entity & SDGT \\
\hline 39 & AL-HARAMAIN : THE NETHERLANDS BRANCH & Entity & SDGT \\
\hline 40 & AL-HARAMAIN : UNITED STATES BRANCH & Entity & SDGT \\
\hline 41 & AL-HARAMAIN FOUNDATION : COMOROS ISLANDS & Entity & SDGT \\
\hline 42 & AL-HARAMAIN ISLAMIC FOUNDATION & Entity & SDGT \\
\hline 43 & AL-HARAMAIN ISLAMIC FOUNDATION & Entity & SDGT \\
\hline 44 & AL-ITIHAAD AL-ISLAMIYA & Entity & SDGT \\
\hline 45 & AL-QA'IDA KURDISH BATTALIONS & Entity & SDGT \\
\hline 46 & AL-QARD AL-HASSAN ASSOCIATION & Entity & SDGT \\
\hline 47 & AL-QUDS INTERNATIONAL FOUNDATION & Entity & SDGT \\
\hline 48 & AL-SALAH SOCIETY & Entity & SDGT \\
\hline 49 & AQSSA SOCIETY YEMEN & Entity & SDGT \\
\hline 50 & ARMED ISLAMIC GROUP & Entity & SDGT \\
\hline 51 & ASAT TRUST REG. & Entity & SDGT \\
\hline 52 & ASKATASUNA & Entity & SDGT \\
\hline 53 & ASSOCIATION DE SECOURS PALESTINIENS & Entity & SDGT \\
\hline 54 & AVIA TRUST FZE & Entity & SDGT \\
\hline 55 & $\begin{array}{l}\text { BA TAQWA FOR COMMERCE AND REAL ESTATE } \\
\text { COMPANY LIMITED }\end{array}$ & Entity & SDGT \\
\hline 56 & BABBAR KHALSA INTERNATIONAL & Entity & SDGT \\
\hline 57 & BANK AL TAQWA LIMITED & Entity & SDGT \\
\hline 58 & BANK SADERAT IRAN & Entity & IFSR, IRAN, SDGT \\
\hline 59 & BANK SADERAT PLC & Entity & IFSR, IRAN, SDGT \\
\hline 60 & BARAKA TRADING COMPANY & Entity & SDGT \\
\hline 61 & BARAKAAT GROUP OF COMPANIES & Entity & SDGT \\
\hline 62 & BARAKAAT INTERNATIONAL COMPANIES & Entity & SDGT \\
\hline 63 & BARAKAAT NORTH AMERICA, INC. & Entity & SDGT \\
\hline 64 & BARAKAAT RED SEA TELECOMMUNICATIONS & Entity & SDGT \\
\hline 65 & $\begin{array}{l}\text { BARAKAAT TELECOMMUNICATIONS COMPANY } \\
\text { LIMITED }\end{array}$ & Entity & SDGT \\
\hline 66 & $\begin{array}{l}\text { BARAKAAT TELECOMMUNICATIONS COMPANY } \\
\text { SOMALIA, LIMITED }\end{array}$ & Entity & SDGT \\
\hline 67 & BARAKAT BANK AND REMITTANCES & Entity & SDGT \\
\hline 68 & BARAKAT COMPUTER CONSULTING & Entity & SDGT \\
\hline 69 & BARAKAT CONSULTING GROUP & Entity & SDGT \\
\hline 70 & BARAKAT GLOBAL TELEPHONE COMPANY & Entity & SDGT \\
\hline 71 & BARAKAT IMPORT EXPORT LTDA & Entity & SDGT \\
\hline 72 & BARAKAT POST EXPRESS & Entity & SDGT \\
\hline 73 & BARAKAT REFRESHMENT COMPANY & Entity & SDGT \\
\hline 74 & BARAKO TRADING COMPANY LLC & Entity & SDGT \\
\hline 75 & BAYT AL-MAL & Entity & SDGT \\
\hline
\end{tabular}




\begin{tabular}{|c|c|c|c|}
\hline \# & Name & Type & Program(s) \\
\hline 76 & BEHINEH TRADING & Entity & IFSR, SDGT \\
\hline 77 & BEHNAM SHAHRIYARI TRADING COMPANY & Entity & IFSR, SDGT \\
\hline 78 & BEIT EL-MAL HOLDINGS & Entity & SDGT, SDT \\
\hline 79 & BENEVOLENCE INTERNATIONAL FOUNDATION & Entity & SDGT \\
\hline 80 & BENEVOLENCE INTERNATIONAL FUND & Entity & SDGT \\
\hline 81 & BIBLOS TRAVEL AGENCY & Entity & SDGT \\
\hline 82 & BLUE SKY AVIATION CO FZE & Entity & SDGT \\
\hline 83 & BOSANSKA IDEALNA FUTURA & Entity & SDGT \\
\hline 84 & CASA APOLLO & Entity & SDGT \\
\hline 85 & CASA HAMZE & Entity & SDGT \\
\hline 86 & CAUCASUS EMIRATE & Entity & SDGT \\
\hline 87 & $\begin{array}{l}\text { COMITE' DE BIENFAISANCE ET DE SECOURS AUX } \\
\text { PALESTINIENS }\end{array}$ & Entity & SDGT \\
\hline 88 & COMMANDER NAZIR GROUP & Entity & SDGT \\
\hline 89 & CONGO FUTUR & Entity & SDGT \\
\hline 90 & CONSPIRACY OF FIRE NUCLEI & Entity & SDGT \\
\hline 91 & $\begin{array}{l}\text { DEMOCRATIC FRONT FOR THE LIBERATION OF } \\
\text { PALESTINE - HAWATMEH FACTION }\end{array}$ & Entity & SDT \\
\hline 92 & DHAMAT HOUMET DAAWA SALAFIA & Entity & SDGT \\
\hline 93 & EASTERN TURKISTAN ISLAMIC MOVEMENT & Entity & SDGT \\
\hline 94 & ELEHSSAN & Entity & SDGT \\
\hline 95 & FATAH AL-ISLAM & Entity & SDGT \\
\hline 96 & $\begin{array}{l}\text { FIRST OF OCTOBER ANTIFASCIST RESISTANCE } \\
\text { GROUP }\end{array}$ & Entity & SDGT \\
\hline 97 & FORENINGEN AL-AQSA & Entity & SDGT \\
\hline 98 & FREE LIFE PARTY OF KURDISTAN & Entity & SDGT \\
\hline 99 & GALERIA PAGE & Entity & SDGT \\
\hline 100 & GLOBAL RELIEF FOUNDATION, INC. & Entity & SDGT \\
\hline 101 & GLOBAL RELIEF FOUNDATION, INC. & Entity & SDGT \\
\hline 102 & GOLFRATE HOLDINGS (ANGOLA) LDA & Entity & SDGT \\
\hline 103 & GOODWILL CHARITABLE ORGANIZATION, INC. & Entity & SDGT \\
\hline 104 & $\begin{array}{l}\text { GRUPO AROSFRAN EMPREENDIMENTOS E } \\
\text { PARTICIPACOES SARL }\end{array}$ & Entity & SDGT \\
\hline 105 & $\begin{array}{l}\text { HAJI KHAIRULLAH HAJI SATTAR MONEY } \\
\text { EXCHANGE }\end{array}$ & Entity & SDGT \\
\hline 106 & HARAKAT-UL JIHAD ISLAMI & Entity & SDGT \\
\hline 107 & HEYATUL ULYA & Entity & SDGT \\
\hline 108 & HILAL TRAVEL AGENCY & Entity & SDGT \\
\hline 109 & $\begin{array}{l}\text { HOLY LAND FOUNDATION FOR RELIEF AND } \\
\text { DEVELOPMENT }\end{array}$ & Entity & SDGT, SDT \\
\hline 110 & $\begin{array}{l}\text { IMAM KHOMEINI RELIEF COMMITTEE (LEBANON } \\
\text { BRANCH) }\end{array}$ & Entity & IFSR, SDGT \\
\hline
\end{tabular}




\begin{tabular}{|c|c|c|c|}
\hline \# & Name & Type & Program(s) \\
\hline 111 & $\begin{array}{l}\text { INTERNATIONAL ISLAMIC RELIEF ORGANIZATION } \\
\text { INDONESIA BRANCH OFFICE }\end{array}$ & Entity & SDGT \\
\hline 112 & $\begin{array}{l}\text { INTERNATIONAL ISLAMIC RELIEF ORGANIZATION } \\
\text { PHILIPPINES BRANCH OFFICE }\end{array}$ & Entity & SDGT \\
\hline 113 & INTERNATIONAL SIKH YOUTH FEDERATION & Entity & SDGT \\
\hline 114 & INTERPAL & Entity & SDGT \\
\hline 115 & $\begin{array}{l}\text { IRANIAN COMMITTEE FOR THE RECONSTRUCTION } \\
\text { OF LEBANON }\end{array}$ & Entity & IFSR, SDGT \\
\hline 116 & ISLAMIC AFRICAN RELIEF AGENCY & Entity & SDGT \\
\hline 117 & ISLAMIC ARMY OF ADEN & Entity & SDGT \\
\hline 118 & ISLAMIC NATIONAL BANK OF GAZA & Entity & SDGT \\
\hline 119 & ISLAMIC RESISTANCE SUPPORT ORGANIZATION & Entity & SDGT \\
\hline 120 & $\begin{array}{l}\text { ISLAMIC REVOLUTIONARY GUARD CORPS (IRGC)- } \\
\text { QODS FORCE }\end{array}$ & Entity & $\begin{array}{l}\text { IFSR, IRGC, SDGT, } \\
\text { SYRIA }\end{array}$ \\
\hline 121 & $\begin{array}{l}\text { JAMIA TALEEM-UL-QURAN-WAL-HADITH } \\
\text { MADRASSA }\end{array}$ & Entity & SDGT \\
\hline 122 & JAM'YAH TA'AWUN AL-ISLAMIA & Entity & SDGT \\
\hline 123 & JIHAD AL-BINA & Entity & SDGT \\
\hline 124 & KAIRABA SUPERMARKET & Entity & SDGT \\
\hline 125 & KYRGYZ TRANS AVIA & Entity & IFSR, SDGT \\
\hline 126 & LAJNAT AL DAAWA AL ISLAMIYYA & Entity & SDGT \\
\hline 127 & LEBANESE MEDIA GROUP & Entity & SDGT \\
\hline 128 & LINER TRANSPORT KISH & Entity & IFSR, SDGT \\
\hline 129 & LOYALIST VOLUNTEER FORCE & Entity & SDGT \\
\hline 130 & MAHAN AIR & Entity & IFSR, SDGT \\
\hline 131 & MAKHTAB AL-KHIDAMAT/AL KIFAH & Entity & SDGT \\
\hline 132 & MAMOUN DARKAZANLI IMPORT-EXPORT COMPANY & Entity & SDGT \\
\hline 133 & MARTYRS FOUNDATION & Entity & IFSR, SDGT \\
\hline 134 & MARTYRS FOUNDATION IN LEBANON & Entity & SDGT \\
\hline 135 & MEADOWBROOK INVESTMENTS LIMITED & Entity & SDGT \\
\hline 136 & MOROCCAN ISLAMIC COMBATANT GROUP & Entity & SDGT \\
\hline 137 & MOVEMENT FOR ISLAMIC REFORM IN ARABIA & Entity & SDGT \\
\hline 138 & $\begin{array}{l}\text { MOVEMENT FOR UNITY AND JIHAD IN WEST } \\
\text { AFRICA }\end{array}$ & Entity & SDGT \\
\hline 139 & MUHAMMAD JAMAL NETWORK & Entity & SDGT \\
\hline 140 & NADA INTERNATIONAL ANSTALT & Entity & SDGT \\
\hline 141 & NADA MANAGEMENT ORGANIZATION SA & Entity & SDGT \\
\hline 142 & ORANGE VOLUNTEERS & Entity & SDGT \\
\hline 143 & OVLAS TRADING S.A. & Entity & SDGT \\
\hline 144 & OZLAM PROPERTIES LIMITED & Entity & SDGT \\
\hline 145 & PALESTINIAN ASSOCIATION IN AUSTRIA & Entity & SDGT \\
\hline 146 & PALESTINIAN MARTYRS FOUNDATION & Entity & SDGT \\
\hline 147 & RABITA TRUST & Entity & SDGT \\
\hline
\end{tabular}




\begin{tabular}{|c|c|c|c|}
\hline \# & Name & Type & Program(s) \\
\hline 148 & RAHAT LTD & Entity & SDGT \\
\hline 149 & RAJAH SOLAIMAN MOVEMENT (RSM) & Entity & SDGT \\
\hline 150 & RED HAND DEFENDERS & Entity & SDGT \\
\hline 151 & RED SEA BARAKAT COMPANY LIMITED & Entity & SDGT \\
\hline 152 & REVIVAL OF ISLAMIC HERITAGE SOCIETY & Entity & SDGT \\
\hline 153 & REVIVAL OF ISLAMIC HERITAGE SOCIETY & Entity & SDGT \\
\hline 154 & REVOLUTIONARY PEOPLE’S STRUGGLE & Entity & SDGT \\
\hline 155 & ROSHAN MONEY EXCHANGE & Entity & SDGT \\
\hline 156 & SANABEL RELIEF AGENCY LIMITED & Entity & SDGT \\
\hline 157 & $\begin{array}{l}\text { SANABIL ASSOCIATION FOR RELIEF AND } \\
\text { DEVELOPMENT }\end{array}$ & Entity & SDGT \\
\hline 158 & SARA PROPERTIES LIMITED & Entity & SDGT \\
\hline 159 & SECT OF REVOLUTIONARIES & Entity & SDGT \\
\hline 160 & SIRJANCO TRADING L.L.C. & Entity & IFSR, SDGT \\
\hline 161 & SNIPER AFRICA & Entity & SDGT \\
\hline 162 & SOMALI INTERNET COMPANY & Entity & SDGT \\
\hline 163 & STICHTING AL-AQSA & Entity & SDGT \\
\hline 164 & $\begin{array}{l}\text { STICHTING BENEVOLENCE INTERNATIONAL } \\
\text { NEDERLAND }\end{array}$ & Entity & SDGT \\
\hline 165 & SYRIAN ARAB AIRLINES & Entity & $\begin{array}{l}\text { IFSR, IRGC, SDGT, } \\
\text { SYRIA }\end{array}$ \\
\hline 166 & TAIBAH INTERNATIONAL : BOSNIA BRANCH & Entity & SDGT \\
\hline 167 & TAJCO & Entity & SDGT \\
\hline 168 & TALIBAN & Entity & SDGT \\
\hline 169 & TAMIL FOUNDATION & Entity & SDGT \\
\hline 170 & TAMILS REHABILITATION ORGANISATION & Entity & SDGT \\
\hline 171 & TEYREBAZEN AZADIYA KURDISTAN & Entity & SDGT \\
\hline 172 & THE AID ORGANIZATION OF THE ULEMA & Entity & SDGT \\
\hline 173 & THE ISLAMIC INTERNATIONAL BRIGADE & Entity & SDGT \\
\hline 174 & $\begin{array}{l}\text { THE RIYADUS-SALIKHIN RECONNAISSANCE AND } \\
\text { SABOTAGE BATTALION OF CHECHEN MARTYRS } \\
\end{array}$ & Entity & SDGT \\
\hline 175 & THE SPECIAL PURPOSE ISLAMIC REGIMENT & Entity & SDGT \\
\hline 176 & TUNISIAN COMBAT GROUP & Entity & SDGT \\
\hline 177 & UKRAINIAN-MEDITERRANEAN AIRLINES & Entity & IFSR, SDGT \\
\hline 178 & ULSTER DEFENCE ASSOCIATION & Entity & SDGT \\
\hline 179 & UMMAH TAMEER E-NAU & Entity & SDGT \\
\hline 180 & UNION OF GOOD & Entity & SDGT \\
\hline 181 & WAAD PROJECT & Entity & SDGT \\
\hline 182 & WAFA HUMANITARIAN ORGANIZATION & Entity & SDGT \\
\hline 183 & WALDENBERG, AG & Entity & SDGT \\
\hline 184 & $\begin{array}{l}\text { WAQFIYA RI'AYA AL-USRA AL-FILISTINYA WA AL- } \\
\text { LUBNANYA }\end{array}$ & Entity & SDGT \\
\hline
\end{tabular}




\begin{tabular}{|l|l|l|l|}
\hline$\#$ & Name & Type & Program(s) \\
\hline 185 & YAS AIR & Entity & IFSR, IRGC, SDGT \\
\hline 186 & YOUSSEF M. NADA & Entity & SDGT \\
\hline 187 & YOUSSEF M. NADA \& CO. GESELLSCHAFT M.B.H. & Entity & SDGT \\
\hline 188 & $\begin{array}{l}\text { YOUSSER COMPANY FOR FINANCE AND } \\
\text { INVESTMENT }\end{array}$ & Entity & SDGT \\
\hline
\end{tabular}

Source: Data adapted from Office of Foreign Asset Control, "SDN Search," http://sdnsearch.ofac. treas.gov/default.aspx (accessed 17 March 2014). 


\section{BIBLIOGRAPHY}

Abrahamian, Ervand. The Iranian Mojahedin. New Haven: Yale University Press, 1989.

Alexander, Yonah, and Michael Kraft, eds. Evolution of U.S. Counterterrorism Policy. Westport, CT: Praeger Security International, 2008.

Cavoli, Christopher G. Toward a Grand Strategy Against Terrorism. Edited by Christopher C. Harmon, Andrew N. Pratt, and Sebastian. Contemporary Learning Series. New York: McGraw Hill Companies, 2011.

Cohen, Ronen. The Rise and Fall of the Mojahedin Khalq, 1987-1997: Their Survival after the Islamic Revolution and Resistance to the Islamic Republic of Iran. Brighton, England: Sussex Academic Press, 2009.

Cronin, Audrey Kurth. "The "FTO List" and Congress: Sanctioning Designated Foreign Terrorist Organizations.” No. RL32120. Congressional Research Service Report for Congress, 2003.

- How Terrorism Ends: Understanding the Decline and Demise of Terrorist Campaigns. Princeton, NJ: Princeton University Press, 2011.

Davis, Paul K., Eric V. Larson, Zachary Haldeman, Mustafa Oguz, and Yashodhara Rana. Understanding and Influencing Public Support for Insurgency and Terrorism. Santa Monica, CA: RAND Corporation, 2012.

Donohue, Laura K. The Cost of Counterterrorism: Power, Politics, and Liberty. Cambridge: Cambridge University Press, 2008.

Evangelista, Matthew. Law, Ethics, and the War on Terror. War and Conflict in the Modern World. Cambridge, UK: Polity, 2008.

Ganor, Boaz. “Defining Terrorism: Is One Man's Terrorist Another Man's Freedom Fighter?” Police Practice and Research 3, no. 4 (2002): 287-304.

- The Counter-Terrorism Puzzle: A Guide for Decision Makers. New Brunswick, NJ: Transaction Publishers, 2005.

Goulka, Jeremiah, Lydia Hansell, Elizabeth Wilke, and Judith Larson. The Mujahedin-e Khalq in Iraq: a Policy Conundrum. Santa Monica, CA: Rand Publishing, 2009.

Gross, Joshua. "Proscription Problems: The Practical Implications of Terrorist Lists on Diplomacy and Peacebuilding in Nepal.” Praxis: The Fletcher Journal of Human Security 26 (2011): 38-59.

Gupta, Dipak K. Understanding Terrorism and Political Violence: The Life Cycle of Birth, Growth, Transformation, and Demise. London: Routledge, 2008.

Harmon, Christopher C. Terrorism Today. 2nd ed. Political Violence. London: Routledge, 2008.

Hoffman, Bruce. Inside Terrorism. Revised ed. New York, NY: Columbia University Press, 2006. 
Hor, Michael Yew Meng, Victor Vridar Ramraj, and Kent Roach, eds. Global Anti-Terrorism Law and Policy. Cambridge, U.K: Cambridge University Press, 2005.

Hutt, Michael. Himalayan People's War: Nepal's Maoist Rebellion. Bloomington: Indiana University Press, 2004.

Jenkins, Brian Michael. Research Paper - California Seminar on Arms Control and Foreign Policy. Vol. no. 48, International Terrorism: a New Mode of Conflict. Los Angeles, CA: Crescent Publications, 1975.

Jongman, Albert J. The Routledge Handbook of Terrorism Research. Edited by Alex Peter Schmid. Routledge Handbooks. New York: Routledge, 2013.

Laqueur, Walter. Terrorism. London: Weidenfeld and Nicolson, 1977.

Lee, Rensselaer. “Terrorist Financing. The U.S. and International Response.” No. RL31658. Congressional Research Service Report for Congress, 2002.

Martin, Gus. Understanding Terrorism: Challenges, Perspectives, and Issues. 3rd ed. Los Angeles, CA: Sage, 2010.

Pillar, Paul R. Terrorism and U.S. Foreign Policy. pbk. ed. Washington, DC: Brookings Institution Press, 2003.

Schmid, Alex, ed. The Routledge Handbook of Terrorism Research (Routledge Handbooks). Reprint ed. New York, NY: Routledge, 2013.

Shelton, Hugh. "Ending Hypocrisy of Terrorist Designation," The Washington Times, 13 October 2011, http://www.washingtontimes.com/news/2011/oct/13/ending-hypocrisy-of-terrorist-designation/ (accessed 13 March 2014).

Tanter, Raymond. Theory and Policy in International Relations. Edited by Richard H. Ullman. Princeton, NJ: Princeton University Press, 1972.

Thapa, Deepak, and Bandita Sijapati. A Kingdom under Siege: Nepal's Maoist Insurgency, 1996 to 2003. updated ed. Kathmandu: The Printhouse, 2004.

Thorup, Mikkel. An Intellectual History of Terror: War, Violence and the State. Routledge Critical Terrorism Studies. London: Routledge, 2012

Torbati, Yeganeh. "Iran Condemns U.S. Removal of MEK from Terrorist List," Reuters, 26 September 2012, http://www.reuters.com/article/2012/09/26/us-iran-usa-idUSBRE88P0B420120926 (accessed 31 March 2014).

U.S. Department of State. Office of the Coordinator for Counterterrorism. Patterns of Global Terrorism 2001. Washington, DC, 2002.

- Office of the Coordinator for Counterterrorism. Patterns of Global Terrorism 2003. Washington, DC, 2004.

—. Office of the Coordinator for Counterterrorism. Country Reports on Terrorism, 2004. 
Washington, DC, 2005.

Office of the Coordinator for Counterterrorism. Country Reports on Terrorism 2012, (Washington, DC, 2013).

United States Department of Defense. Department of Defense Dictionary of Military and Associated Terms: Joint Publication 1-02. Washington D.C., 2012.

Vaughn, Bruce. "Nepal: Background and U.S. Relations.” No. RL31599. Congressional Research Service Report for Congress, 2006.

Whelpton, John. A History of Nepal. Cambridge: Cambridge University Press, 2005.

Wilkinson, Paul. Terrorism versus Democracy: The Liberal State Response. 2nd ed. Cass Series: Political Violence. London: Routledge, 2006.

Materials Cited in Footnotes

Antiterrorism and Effective Death Penalty Act of 1996, Public Law 104-132, § 302, U.S. Statutes at Large 110 (1996): 1248-50, codified at U.S. Code 8 (2012), § 1189(d).

Antiterrorism and Effective Death Penalty Act of 1996, Public Law 104-132, § 303a, U.S. Statutes at Large 110 (1996): 1250-53, codified at U.S. Code 18 (2012), § 2339B.

Antiterrorism and Effective Death Penalty Act of 1996, Public Law 104-132, § 303a, U.S. Statutes at Large 110 (1996): 1250-53, codified at U.S. Code 18 (2012), § 2339B(a)(1).

Bush, George W.. Executive Order 13224. "Blocking Property and Prohibiting Transactions With Persons Who Commit, Threaten To Commit, or Support Terrorism.” Federal Register 66, no. 186 (25 September 2001): 49079-49080.

Foreign Relations Authorization Act, Fiscal Years 1988 and 1989, Public Law 100-204, § 140, U.S. Statutes at Large 101 (1987): 1347-49, codified at U.S. Code 22 (2012), § 2656f(d)(2).

Georgetown University Center for Peace and Security Studies. "Bruce Hoffman.” Georgetown University. http://explore.georgetown.edu/people/brh6/ (accessed 19 March 2014.

Georgetown University Center for Security Studies. "Paul R Pillar.” Georgetown University. http://explore.georgetown.edu/people/prp8/ ?action=viewpublications\&PageTemplateID=360 (accessed 19 March 2014).

Holder v. Humanitarian Law Project, 561 US 16, 17 (2010)

In Re: People's Mojahedin Organization of Iran. No. 12-1118, slip op. (D.C. Cir. 1 June 2012).

Intelligence Reform and Terrorism Prevention Act of 2004. Public Law 108-458, § 7102, U.S. Statutes at Large 118 (2004): 3777-78, codified at U.S. Code 22 (2012), § $2656 \mathrm{f}$.

International Institute for Counter-Terrorism. "Boaz Ganor, Ph.d." http://www.ict.org.il/Biographies/ DrBoazGanor/tabid/152/Default.aspx (accessed 19 March 2014). 
Merriam-Webster Dictionary. s.v. “effective," http://www.merriam-webster.com/dictionary/effective (accessed 13 March 2014).

_. s.v. "efficacy," http://www.merriam-webster.com/dictionary/efficacy (accessed 13 March 2014).

Office of Foreign Asset Control. "SDN Search.” http://sdnsearch.ofac. treas.gov/default.aspx (accessed 17 March 2014).

Peoples Mojahedin Organization of Iran v. U.S. Department of State. 613 F.3d 220 (D.C. Cir. 2010).

San Diego State University Department of Political Science. "Dr. Dipak Gupta, Political Science.” San Diego State University. http://www-rohan.sdsu.edu/ dgupta/ (accessed 19 March 2014).

U.S. Department of State. "Delisting of the Mujahedin-E Khalq." http://www.state.gov/r/pa/prs/ps /2012/09/198443.htm (accessed 20 March 2014).

."Foreign Terrorist Organizations." http://www.state.gov/j/ct/rls/other/ des/123085.htm (accessed 14 March 2014).

. Office of the Coordinator for Counterterrorism. "Fact Sheet, Foreign Relations Authorization Act, Fiscal Years 1988 and 1989: Terrorism Definition." 8 April 2008. http://20012009.state.gov/s/ct/rls/fs/08/103401.htm (accessed 12 December 2013).

_. Office of the Coordinator for Counterterrorism. "Introduction Global Patterns of Terrorism 1996." http://www.state.gov/www/global/ terrorism/1996Report/1996index.html (accessed 15 March 2014).

—_. "Individuals and Entities Designated by the State Department Under E.O. 13224." http://www.state.gov/j/ct/rls/other/des/ 143210.htm (accessed 19 March 2014).

_. "Terrorist Exclusion List." http://www.state.gov/j/ct/rls/other/des/123086.htm (accessed 14 December 2013).

U.S. Department of Treasury. "Office of Foreign Assets Control Frequently Asked Questions." http://www.treasury.gov/resource-center/faqs/Sanctions /Pages/answer.aspx\#60 (accessed 18 December 2013).

Uniting and Strengthening America by Providing Appropriate Tools Required to Intercept and Obstruct Terrorism (USA PATRIOT ACT) Act of 2001, Public Law 107-56, § 411, U.S. Statutes at Large 115 (1996): 345-48, codified at U.S. Code 8 (2012), § 1182(3)(B).

Violent Crime Control and Law Enforcement Act of 1994. Public Law 103-322, § 120005. U.S. Statutes at Large 108 (1994): 2022-22, codified at U.S. Code 18 (2012), §2339A(b)(1).

Sources Consulted

Costigan, Sean S., and David Gold. Terrornomics. Aldershot, England: Ashgate, 2007. http://site.ebrary.com/id/10211327 (accessed 19 March 2014). 
Doyle, Charles. “Antiterrorism and Effective Death Penalty Act of 1996: A Summary.” Washington D.C., USA. UNT Digital Library. http://digital.library.unt.edu/ark:/67531/metacrs309/.(accessed 8 March 2014).

Dunn Cavelty, Myriam, and Victor Mauer, eds. The Routledge Handbook of Security Studies. paperback ed. Routledge Handbooks. Milton Park, Abingdon, Oxon: Routledge, 2010.

Gurulé, Jimmy. Unfunding Terror: The Legal Response to the Financing of Global Terrorism. Cheltenham, UK: Edward Elgar, 2008.

Hoge, James F., and Gideon Rose, eds. How Did This Happen? Terrorism and the New War. Publicaffairs Reports. New York: PublicAffairs, 2001.

Kean, Thomas H., and Lee Hamilton. The 911 Commission Report: Final Report of the National Commission On Terrorist Attacks Upon the United States. official government ed. Washington, D.C.: National Commission on Terrorist Attacks upon the United States, 2004.

Malik, Omar. Enough of the Definition of Terrorism. London: Royal Institute of International Affairs, 2000.

Ranstorp, Magnus, ed. Mapping Terrorism Research: State of the Art, Gaps and Future Direction. Cass Series: Political Violence. London: Routledge, 2007.

Reagan, Ronald W. "Radio Address to the Nation on Terrorism." http://www.reagan.utexas.edu/archives/ speeches/1986/53186a.htm (accessed 10 December 2013).

Strasser, Steven, and Craig R. Whitney, eds. The 911 Investigations: Staff Reports of the 911 Commission. Publicaffairs Reports. New York: PublicAffairs, 2004.

Thorup, Mikkel. An Intellectual History of Terror: War, Violence and the State. Critical Terrorism Studies. London: Routledge, 2010.

U.S. Department of State. "Delisting of the Communist Party of Nepal (Maoist)." http://www.state.gov/r/pa/prs/ps/2012/09/197411.htm (accessed 20 March 2014).

- Office of the Coordinator for Counterterrorism. Patterns of Global Terrorism 2002. Washington, DC, 2003.

- Office of the Coordinator for Counterterrorism. Country Reports on Terrorism, 2008. Washington, DC, 2009.

- Office of the Coordinator for Counterterrorism. Country Reports on Terrorism, 2009. Washington, DC, 2010.

- Office of the Coordinator for Counterterrorism. Country Reports on Terrorism, 2010. Washington, DC, 2011.

Office of the Coordinator for Counterterrorism. Country Reports on Terrorism, 2011. Washington, DC, 2012. 